\title{
Over-Production of P60 Family Proteins, Glycolytic and Stress Response Proteins Characterizes the Autolytic Profile of Listeria monocytogenes
}

\author{
Elsa Pinto ${ }^{1}$, Natália Marques ${ }^{2}$, Peter W. Andrew ${ }^{3}$, M. Leonor Faleiro ${ }^{1^{*}}$ \\ ${ }^{1}$ Centro de Biomedicina Molecular e Estrutural (IBB), Faculdade de Ciências e Tecnologia, Universidade do Algarve, Faro, Portugal \\ ${ }^{2}$ BioFig, Faculdade de Ciências e Tecnologia, Universidade do Algarve, Faro, Portugal \\ ${ }^{3}$ Department of Infection, Immunity and Inflammation, University of Leicester, Leicester, UK \\ Email: *mfaleiro@ualg.pt
}

Received April 11, 2012; revised April 27, 2012; accepted May 10, 2012

\begin{abstract}
Listeria monocytogenes is a foodborne pathogen capable of surviving under challenging conditions both outside and inside the host. During the transition from exponential to stationary phase it experiences a series of environmental changes that require an appropriate response to maintain cell viability. In this study the autolytic behaviour of a $L$. monocytogenes strain was investigated by two-dimensional electrophoresis. The study was done at the permissive autolysis temperature, $30^{\circ} \mathrm{C}$ and at $20^{\circ} \mathrm{C}$, an autolysis non-permissive temperature. An autolytic strain proteome was also compared to a non-autolytic strain at the permissive autolysis temperature. The autolytic strain proteome at $30^{\circ} \mathrm{C}$ in comparison to $20^{\circ} \mathrm{C}$ evidenced increased synthesis of the P60 autolysin, glycolytic enzymes and proteins related with environmental stress responses. The over-production of $\mathrm{P} 45$ autolysin, was observed when the autolytic strain proteome was compared with the non-autolytic strain. The proteomes at the non-permissive temperature and the proteome of the non-autolytic strain were characterized by a diminished synthesis of several stress related proteins. The lack of autolysis seems to be associated to the over-production of proteins linked to fatty acid and amino acid synthesis, transcription regulation and cell morphogenesis as evidenced by the proteome at the non-permissive temperature and the non-autolytic strain. Autolysis proteome evidenced the over-production of P60 autolysins, glycolysis and stress proteins whereas the proteome obtained in conditions of absence of autolysis reveal a completely different group of proteins. Possible targets to activate listerial autolysis were identified.
\end{abstract}

Keywords: Listeria monocytogenes; Autolysis Proteome; Stress Proteins

\section{Introduction}

Autolysis in Listeria monocytogenes, a Gram-positive bacterium associated with the foodborne disease listeriosis, has been known for a long time [1,2]. The phenomenon occurs as a result of the activity of peptidoglycan hydrolases called autolysins [3]. These peptidoglycan hydrolases can participate in a significant number of important biological processes, namely in cell wall turnover, cell separation, cell division and their contribution in pathogenicity, either for Gram positive (e.g. Streptococcus pneumoniae, Staphylococcus aureus) and Gram negative bacteria (e.g. Helicobacter pylori) [4-6], also has been demonstrated. In L. monocytogenes, six autolysins have been identified P60, P45, Ami, Mur, Auto and the Lmo0327 [7-13] and at least three of these autolysins, P60, Ami and Auto are involved in survival and viru-

${ }^{*}$ Corresponding author. lence of L. monocytogenes [8,14,15].

The peptidoglycan hydrolases constitute a distinctive family of enzymes whose principal function is to exactly cut the peptidoglycan in order that new murein strands can be inserted. Their activity must be firmly controlled to avoid the strand breakage resulting in cell lysis. The autolysis process is widespread amongst bacteria and other microorganisms, such as yeast and fungi (e.g. Saccharomyces cerevisae and Aspergillus nidulans) [16,17]. In Gram positive bacteria, teichoic acids are considered the principal regulators of the peptidoglycan hydrolases $[18,19]$. The binding of murein hydrolases to teichoic acids is mediated by repeat elements known as cholinebinding domains [20] and the connection of murein hydrolases to the cell wall occurs through the modification of teichoic acids. The addition of D-alanine ester linkages to teichoic acids modifies the surface charge and protects the cell from autolysis [21]. Besides the require- 
ment for choline-binding domains and D-alanylation of teichoic acids, other studies have demonstrated that pyruvylation of unspecified carbohydrates (presumably teichoic acids) also contribute to the control of the murein hydrolases; namely a Bacillus anthracis mutant defective in $c s a A B$ genes, that are responsible for pyruvylation, displayed deficient cell division and autolysis [22]. Autolysis can be induced by the action of different factors, namely the dissipation of proton motive force (PMF) across the cell membrane, increase of cell wall $\mathrm{pH}$, temperature mineral salts, ethanol and EDTA [23-25].

In our laboratory we found the process of autolysis in L. monocytogenes is more complex than may have been thought previously, with different strains of L. monocytogenes having very great differences in the pattern of their autolysis. For example, some L. monocytogenes isolates promptly and consistently undergo autolysis when grown in minimal medium, whereas other strains do not. Clearly there are differences in the control of autolysis in these strains but to date it is unknown how L. monocytogenes autolysins are regulated.

The objective of this study was to compare the intracellular proteome and the extracellular proteome of two L. monocytogenes strains that differ in the propensity to autolysis, one that had a propensity to autolyse and one which did not. Differences in the proteomes of these two strains provided important clues about this cellular process that can result in cell death and can be further explored to trigger listerial death in contaminated foods.

\section{Material and Methods}

\subsection{Bacterial Strains and Growth Conditions}

Two strains of L. monocytogenes were used in this study, C897 (a cheese isolate of 1/2a serotype prone to autolysis) and EGD (a clinical isolate of $1 / 2$ a serotype and a nonautolytic strain). For routine growth of listeria, tryptic soy agar medium (Merck, Darmstadt, Germany) was used at $30^{\circ} \mathrm{C}$. To study the protein synthesis under autolysis, the defined medium of Trivett and Meyer [26] (TM) was used. This medium has been used to investigate physiological responses in L. monocytogenes [1,27,28]. These cultures were incubated at two temperatures, at $30^{\circ} \mathrm{C}$ at which the autolysis process is observed in C897 and at $20^{\circ} \mathrm{C}$ at which autolysis is absent. The culture at both temperatures was done with shaking (120 rpm). All listeria cultures were inoculated to obtain an initial optical density at $600 \mathrm{~nm}\left(\mathrm{OD}_{600 \mathrm{~nm}}\right)$ of $0.02-0.05$, using $16 \mathrm{~h}$ overnight cultures in TM as inocula.

\subsection{Induction of Lysis by Penicillin G}

Penicillin induction of lysis was done according to
Fontana et al. [29]. Overnight listeria cultures were diluted in fresh medium to obtain an initial optical density at $600 \mathrm{~nm}\left(\mathrm{OD}_{600 \mathrm{~nm}}\right)$ of $0.02-0.05$ and left to grow at $37^{\circ} \mathrm{C}$, with shaking, until they reached $\mathrm{OD}_{600 \mathrm{~nm}}$ of $0.15-$ 0.2 . Penicillin $\mathrm{G}(100 \mathrm{U} / \mathrm{ml})$ was added to the cultures and the $\mathrm{OD}_{600 \mathrm{~nm}}$ was measured over $6 \mathrm{~h}$ and after $24 \mathrm{~h}$. The viability was determined at the time of penicillin addition and at the end of $24 \mathrm{~h}$ using the drop method [30].

\subsection{Protein Extracts and Protein Determination}

Listeria cultures were grown until the end of exponential phase $\left(\mathrm{OD}_{600 \mathrm{~nm}}=0.5-0.6\right)$ and the cells were collected by centrifugation $\left(3000 \times \mathrm{g}, 10 \mathrm{~min}\right.$ at $\left.4^{\circ} \mathrm{C}\right)$. The protein extraction from the supernatant was done according to Trost et al. [31]. Briefly, the listerial cultures were centrifuged to eliminate the bacterial cells and the supernatant was filtered using $0.22 \mu \mathrm{m}$ filters. Protein precipitation was initiated by the addition of PMSF $(0.2 \mathrm{mM})$ and sodium-deoxycholate $(0.2 \mathrm{mg} / \mathrm{ml})$ to the samples and incubation on ice for $30 \mathrm{~min}$. Afterwards, TCA (7\%, w/v) was added and the samples were incubated overnight at $4^{\circ} \mathrm{C}$. The samples were centrifuged at $4020 \times \mathrm{g}$ for 15 $\min$ at $4^{\circ} \mathrm{C}$. The supernatant was removed and the protein pellet was washed twice with cold acetone. The pellet was air-dried and the protein was dissolved in solubilisation buffer (7 M urea, $2 \mathrm{M}$ thiourea, 4\% (w/v) CHAPS, $40 \mathrm{mM}$ DTT, $0.8 \%(\mathrm{v} / \mathrm{v})$ pharmalyte $\mathrm{pH} 4-7$ (GE Healthcare). The samples were maintained at $-80^{\circ} \mathrm{C}$ until analyzed.

The protein extraction from the bacterial cells was done according to Folio et al. [32]. The collected cells were immediately washed after sampling with washing buffer (100 mM Tris-HCl pH 7.0, $100 \mathrm{mM}$ EDTA and $0.1 \mathrm{ml} 100 \times$ protease inhibitor mix (GE Healthcare, Madrid, Spain). Cell samples were resuspended in lysis buffer $(25 \mathrm{mM}$ Tris-HCl pH 7.0, $25 \mathrm{mM}$ EDTA, 1\% (v/v) DTT and $0.25 \mathrm{ml}$ of $100 \times$ protease inhibitor mix) and were lysed by sonication on ice for $15 \mathrm{~min}$. Contaminating nucleic acids were eliminated by the addition of $1 \mu 1$ (1 unit) DNase RQ1 (Promega) and $5 \mu$ RNase A (10 $\mathrm{mg} / \mathrm{ml}$, Promega). The samples were centrifuged at 3000 $\times \mathrm{g}$ for $10 \mathrm{~min}$ at $4^{\circ} \mathrm{C}$ and acetone $(5 \times$ the volume of the supernatant) was added to each sample. The proteins were precipitated at $-20^{\circ} \mathrm{C}$ for $1 \mathrm{~h}$ and collected by centrifugation $\left(18,000 \times \mathrm{g}\right.$ for $30 \mathrm{~min}$ at $\left.4^{\circ} \mathrm{C}\right)$. Samples were air-dried and proteins were solubilised by the addition of $400 \mu$ solubilisation buffer (7 M urea, $2 \mathrm{M}$ thioureia, 4\% (w/v) CHAPS, $40 \mathrm{mM}$ DTT, 0.8\% (v/v) Pharmalyte [GE Healthcare]). The total protein concentration was determined by using a Bio-Rad Protein Assay kit, according to the manufacturer's instructions. The protein samples were kept at $-80^{\circ} \mathrm{C}$ until use. 


\subsection{Two-Dimensional Gel Electrophoresis (2-DE) and Image Analysis}

The protein profile of the cell extracts and the supernatant of the L. monocytogenes cultures were analyzed by 2 -DE. Approximately $300-400 \mu \mathrm{g}$ of protein was used. The protein samples were separated in the first dimension using an $18 \mathrm{~cm} \mathrm{pH} 3-10$ or $\mathrm{pH} 4-7$ Immobiline Dry Strip (GE Healthcare). Rehydration and isoelectric focusing was done using an IPGphor Isoelectric Focusing System (GE Healthcare). The Immobiline strips were re-hydrated for $11 \mathrm{~h}$ at $20^{\circ} \mathrm{C}, 30 \mathrm{~V}$ and $50 \mu \mathrm{A} /$ strip. Proteins were focused at $20^{\circ} \mathrm{C}, 50 \mu \mathrm{A} /$ strip, $100 \mathrm{~V}$ for $1 \mathrm{~h}$, $500 \mathrm{~V}$ for $1 \mathrm{~h}$ and then a gradient at $8000 \mathrm{~V}$ with a final voltage from $8000 \mathrm{~V}$ until $60,000 \mathrm{Vhr}$. After isoelectric focusing, the strips were maintained at $-80^{\circ} \mathrm{C}$ or were immediately placed in an equilibration buffer $(6 \mathrm{M}$ urea, $75 \mathrm{mM}$ Tris- $\mathrm{HCl} \mathrm{pH} 8.8,2 \%(\mathrm{w} / \mathrm{v})$ SDS, 29.3\% (v/v) glycerol, $0.002 \%(\mathrm{w} / \mathrm{v})$ bromophenol blue and $10 \mathrm{mg} / \mathrm{ml}$ DTT (GE Healthcare) for 20 min. After this first step, the strips were transferred to fresh equilibration buffer supplemented with $25 \mathrm{mg} / \mathrm{ml}$ iodoacetamide (GE Healthcare). Protein separation in the second dimension was performed in $12.5 \%(\mathrm{w} / \mathrm{v})$ SDS-polyacrylamide gels in an Ettan Dalt six apparatus (GE Healthcare). The gels were run in triplicate to confirm the reproducibility of the protein patterns. Protein spots were visualised by Coomassie Blue R-250 staining. The determination of the protein profiles was done using an Image Scanner II (GE Healthcare), in combination with computational image analysis done by using Image Master 2D Platinum software, version 6 (GE Healthcare). The statistical analysis was performed using the Student's t-test (confidence level 0.05 and 0.01). Mean normalized spot volume, standard deviation (SD) and coefficient of variance $(\mathrm{CV})$ were determined for each spot.

\subsection{Protein Identification}

The spots of interest were manually excised from the stained 2-DE gels and analyzed by MALDI-TOF or LCMS/MS by the Protein and Nucleic Acid Chemistry Laboratory at the University of Leicester, UK or Aberdeen Proteome Facility (extracellular spots) and proteins were identified using MASCOT software.

\section{Results and Discussion}

Listeria monocytogenes as many other bacterial pathogens meets a variety of challenging conditions either outside or inside the host, including insufficiency in nutrients (carbon, nitrogen, iron, and other nutrients), $\mathrm{pH}$ variations, oxidative stress and strong adverse conditions directed by the host innate and adaptive immune responses. The successful establishment of infection largely depends on the bacterial ability to modify and adjust their physiological state and virulence phenotype in agreement with the encountered challenging conditions. Bacterial cells exhibit growth-phase dependent physiological events and during the entry into the stationary phase an autolysis process may be trigger. The stationary growth phase is defined as the time that bacterial growth rate starts to decline and the development of multiple stress responses on promotion of survival can be activated. The comprehension of the cellular events at this time point of the growth phase is vital to fully understand the mechanisms of listerial response to environmental changes. The autolytic behaviour of L. monocytogenes C897 was observed when grown in the chemically defined TM medium at $30^{\circ} \mathrm{C}$, whereas autolysis was not seen with EGD in $\mathrm{TM}$ at $30^{\circ} \mathrm{C}$ (Figure 1(a)). Consistent with this difference, C897 was more susceptible to lysis by penicillin (Figure 1(b)).

In contrast to the events at $30^{\circ} \mathrm{C}$, at lower growth temperature $\left(20^{\circ} \mathrm{C}\right)$ the autolysis process was not observed in C897 (Figure 1(c)). The generation time achieved by the autolytic strain and non-autolytic strain when grown at $30^{\circ} \mathrm{C}$ was $2.33 \pm 0.02 \mathrm{~h}$ and $2.08 \pm 0.06 \mathrm{~h}$, respectively and were not significantly different $(\mathrm{P}<0.05)$.

To understand the events leading up to autolysis, two proteomic analysis were done: 1) the autolytic extracellular proteome $\left(\mathrm{C} 897\right.$ grown at $\left.30^{\circ} \mathrm{C}\right)$ was compared to the non-autolytic extracellular proteome (C897 grown at $20^{\circ} \mathrm{C}$ ), and to the extracellular proteome of the nonautolytic strain EGD grown at $\left.30^{\circ} \mathrm{C}, 2\right)$ the autolytic intracellular proteome $\left(\mathrm{C} 897\right.$ grown at $\left.30^{\circ} \mathrm{C}\right)$ was compared to the non-autolytic intracellular proteome (C897 grown at $20^{\circ} \mathrm{C}$ ) and to the non-autolytic intracellular proteome of EGD grown at $30^{\circ} \mathrm{C}$.

\subsection{The Intracellular Proteome of the Autolytic Strain at Autolysis Condition}

It was expected that the analysis of the intracellular proteome would reveal the cellular events that may be deregulated to allow the development of autolysis and also the cells' efforts to control this potentially lethal cellular event. To accomplish this the intracellular proteome of the autolytic strain C897 at an autolysis condition $\left(30^{\circ} \mathrm{C}\right)$ was compared to the intracellular proteome at a nonautolysis condition $\left(20^{\circ} \mathrm{C}\right)$ and to the intracellular proteome of the non-autolytic strain EGD $\left(30^{\circ} \mathrm{C}\right)$. Data are summarized in Table 1. A representative gel of each experiment is shown in Figure 2(a). Twenty proteins were significantly more expressed $(\mathrm{P}<0.05)$ by the autolytic strain, $\mathrm{C} 897$, at $30^{\circ} \mathrm{C}$ in comparison to the intracellular proteome at the non-autolysis condition $\left(20^{\circ} \mathrm{C}\right)$. The identified proteins are distributed in ten functional categories, with some of these categories including at least three 


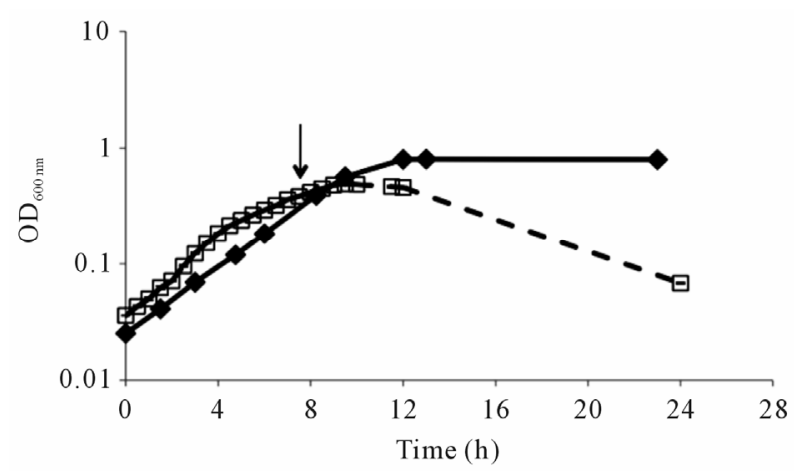

(a)

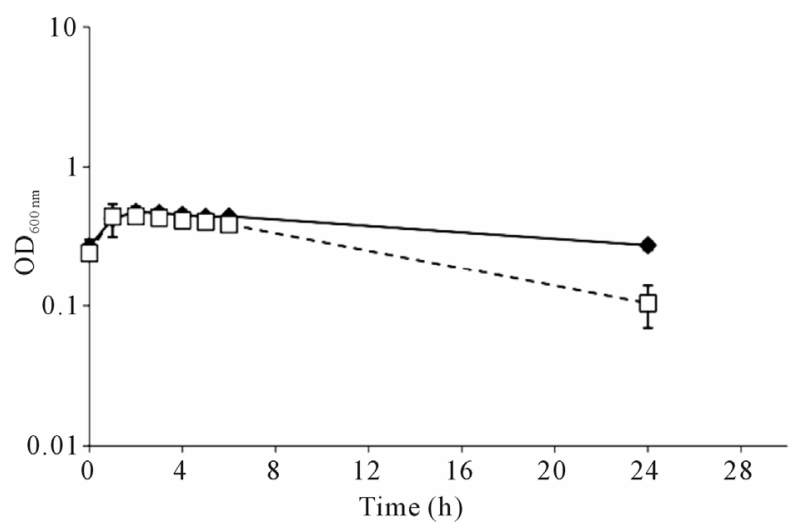

(b)

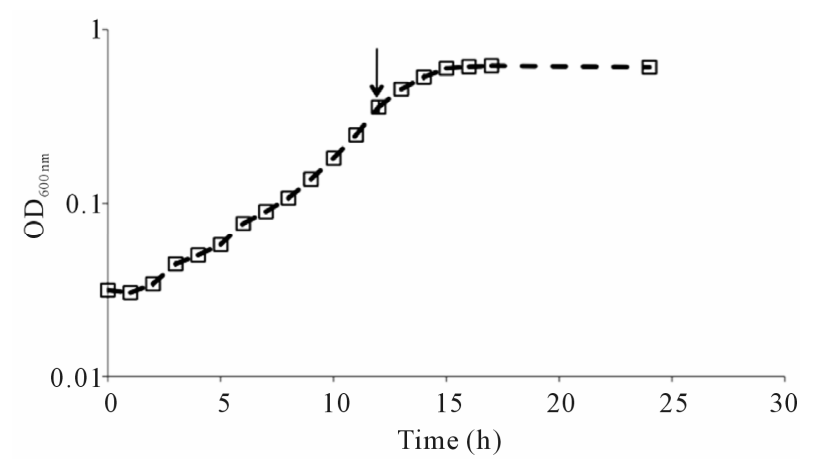

(c)

Figure 1. Autolysis behaviour of Listeria monocytogenes C897. (a) growth of L. monocytogenes C897 ( $\square$ ) and EGD $(\diamond)$ in $\mathrm{TM}$ medium at $30^{\circ} \mathrm{C}$; (b) induction of lysis by penicillin G in L. monocytogenes C897 ( $\square$ ) and EGD ( $\diamond)$ cultures in $\mathrm{BHI}$ at $37^{\circ} \mathrm{C}$, (c) growth of L. monocytogenes C897 in TM medium at $20^{\circ} \mathrm{C}$. Data are the mean of three to four independent experiments. The standard error bars are within the area of the symbols in (a) and (c). The arrow indicates the time point at which samples were taken for 2-DE analysis.

proteins, which may indicate a higher importance of these cellular events in the autolysis process or its control. These categories are glycolysis, metabolism of amino acids and related molecules and the adaptation to stress conditions. A noteworthy aspect is the increased expression of six proteins of glycolysis, namely pyruvate ki- nase, phosphoglycerate kinase, enolase, glyceraldehyde 3-phosphate dehydrogenase (Gap protein), L-lactate dehydrogenase 1 (LDH-1) and Lmo 1634 (similar to alcohol dehydrogenase). The overproduction of six proteins involved in glucose metabolism by the autolytic strain indicates a strong need for energy.

Two proteins involved in the use of glucose were also over-produced by the C897 strain. These proteins, the phosphocarrier protein Hpr (spot 88) and the catabolite control protein CcpA (spot 31), are involved in the carbon catabolite repression (CCR) process (Table 1). The involvement of CcpA in stress responses of $L$. monocytogenes has been observed when listerial cells were exposed to salt stress [33]. Moreover the simultaneous overproduction of CcpA and the chaperones DnaK and GroEL (Table 1) was already reported for Lactobacillus plantarum [34] and L. monocytogenes [35] so is possible that CcpA may operate as a positive regulator of the two chaperones. Regarding the proteins involved in metabolism of amino acids and related molecules it is noteworthy that there was an increased synthesis of cysteine synthase (CysK) and D-alanine aminotransferase (DaaA). It is known that CysK is over-produced in B. subtilis under cold and oxidative stresses [36,37]. D-alanine is a key element in the synthesis of murein and one of the principal proteins involved in its synthesis is the Dalanine aminotransferase, which catalyzes the conversion of D-glutamic acid to $\alpha$-ketoglutaric acid and D-alanine. The deletion of the genes that encode D-alanine aminotransferase (dat or daaA) and alanine racemase (dal) produces a phenotype that is entirely dependent on exogenous alanine and its absence induces lysis of $L$. monocytogenes cells in log phase of growth [38]. The over-expression of these two proteins under autolysis condition is indicative of the fatal murein break due to autolysis in C897 cells.

\subsection{In Autolysis Condition the Autolytic Strain Shows a Stress Adaptation Response}

The intracellular proteome of the $\mathrm{C} 897$ strain at $30^{\circ} \mathrm{C}$, in comparison to the intracellular proteome at the nonautolysis condition $\left(20^{\circ} \mathrm{C}\right)$, revealed the over-production of five proteins associated with adaptation to stress conditions (Table 1) and one of these were also over-produced by $\mathrm{C} 897$ at $30^{\circ} \mathrm{C}$, in comparison to $\mathrm{EGD}$ at $30^{\circ} \mathrm{C}$. Three proteins, in particular, that fit into the functional category of adaptation to atypical conditions were identified; namely the general stress protein Ctc, peroxide resistance protein Dpr and the Lmo1601 protein (stress protein-like protein). Two other protein spots related with stress response, the DnaK protein and the $60 \mathrm{KDa}$ chaperonine, GroEL also were identified (Table 1).

The over-expression of Ctc in L. monocytogenes exposed to stress conditions, namely cold, salt and osmotic 
Table 1. Differentially expressed intracellular proteins. Differential protein abundance is indicated as fold change (minimum 2-fold, $P<0.05)$.

\begin{tabular}{|c|c|c|c|c|c|c|}
\hline $\begin{array}{l}\text { Functional category or } \\
\text { description }\end{array}$ & $\begin{array}{l}\text { Spot } \\
\text { ID }\end{array}$ & Gene name & Locus name & UniProt ID & Protein name & $\begin{array}{l}\text { Fold } \\
\text { Change }^{\mathrm{a}}\end{array}$ \\
\hline \multicolumn{7}{|c|}{ More abundant proteins in the autolytic strain $\mathrm{C} 897$ at $30^{\circ} \mathrm{C}$ (autolysis condition) in comparison to $20^{\circ} \mathrm{C}$ (non-autolysis condition) } \\
\hline $\begin{array}{l}\text { Transport/binding proteins } \\
\text { and lipoproteins }\end{array}$ & 88 & pts $H$ & LMOf6854_1051 & Q4ER91_LISMO & Phosphocarrier protein HPr & 2.0 \\
\hline Specific pathways & $\underline{3}$ & pykA & $1 \mathrm{mo} 1570$ & Q8Y6W1_LISMO & Pyruvate kinase & 3.6 \\
\hline Specific pathways & $\underline{33}$ & $l d h 1$ & LMOf2365_0221 & LDH1_LISMF & L-lactate dehydrogenase 1 & 2.3 \\
\hline Specific pathways & 91 & & $\operatorname{lmo} 1634$ & Q8Y6Q0_LISMO & $\begin{array}{l}\text { Lmo1634 protein (similar to } \\
\text { alcohol dehydrogenase) }\end{array}$ & 24.1 \\
\hline Main glycolytic pathways & 16 & eno & LMOh7858_2604 & Q4EEP6_LISMO & Enolase & 2.0 \\
\hline Main glycolytic pathways & $32^{\mathrm{b}}$ & gap & $\operatorname{lmo} 2459$ & Q8Y4I1_LISMO & $\begin{array}{l}\text { Glyceraldehyde 3-phosphate } \\
\text { dehydrogenase (Gap protein) }\end{array}$ & 2.0 \\
\hline Main glycolytic pathways & $\underline{196}$ & $p g k$ & $\operatorname{lmo} 2458$ & PGK_LISMO & Phosphoglycerate kinase & 3.1 \\
\hline $\begin{array}{l}\text { Metabolism of aminoacids } \\
\text { and related molecules }\end{array}$ & $\underline{13}$ & hom & LMOf6854_2608 & Q4EPH5_LISMO & Homoserine dehydrogenase & 2.6 \\
\hline $\begin{array}{l}\text { Metabolism of aminoacids } \\
\text { and related molecules }\end{array}$ & 40 & cys $K$ & $\operatorname{lmo} 0223$ & Q8YAC3_LISMO & Cysteine synthase & 2.0 \\
\hline $\begin{array}{l}\text { Metabolism of aminoacids } \\
\text { and related molecules }\end{array}$ & $\underline{41}$ & dat & $\operatorname{lmo} 1619$ & DAAA_LISMO & D-alanine aminotransferase & 2.1 \\
\hline Regulation & $\underline{31}$ & cсpA & LMOf6854_1652 & Q4EP90_LISMO & $\begin{array}{l}\text { Catabolite control protein A } \\
\text { (Fragment) }\end{array}$ & 2.3 \\
\hline Elongation & 17 & tuf & LMOh7858_2914 & Q4EJM9_LISMO & Elongation factor $\mathrm{Tu}$ & 2.0 \\
\hline Protein folding & $\underline{4}$ & dnaK & LMOh7858_1570 & Q4EGL2_LISMO & Chaperone protein DnaK & 2.5 \\
\hline Protein folding & $\underline{5}$ & groEL & LMOh7858_2197 & Q4EEZ8_LISMO & $60 \mathrm{kDa}$ chaperonin, GroEL & 3.6 \\
\hline $\begin{array}{l}\text { Adaptation to atypical } \\
\text { conditions }\end{array}$ & 47 & $c t c$ & BSU00520 & A1E155_LISMO & General stress protein $\mathrm{Ctc}$ & 2.0 \\
\hline $\begin{array}{l}\text { Adaptation to atypical } \\
\text { conditions }\end{array}$ & 77 & & LMOf6854_0989 & Q4ERJ3_LISMO & Peroxide resistance protein Dpr & 4.0 \\
\hline $\begin{array}{l}\text { Adaptation to atypical } \\
\text { conditions }\end{array}$ & 104 & & $\operatorname{lmo} 1601$ & Q9RQJ0_LISMO & $\begin{array}{l}\text { Lmo1601 protein (Stress } \\
\text { protein-like protein) }\end{array}$ & 2.0 \\
\hline $\begin{array}{c}\text { Formate-tetrahydrofolate } \\
\text { ligase activity }\end{array}$ & $\underline{11}$ & fhs & LMOh7858_2002 & Q4EH88_LISMO & Formate-tetrahydrofolate ligase & 2.0 \\
\hline \multicolumn{7}{|c|}{ More abundant proteins in the autolytic strain $\mathrm{C} 897$ at $30^{\circ} \mathrm{C}$ in comparison to the non autolytic strain EGD at $30^{\circ} \mathrm{C}$} \\
\hline Specific pathways & $\underline{3}$ & pykA & $\operatorname{lmo} 1570$ & Q8Y6W1_LISMO & Pyruvate kinase & 6.3 \\
\hline Specific pathways & $\underline{33}$ & $l d h 1$ & LMOf2365_0221 & LDH1_LISMF & L-lactate dehydrogenase 1 & 2.0 \\
\hline Main glycolytic pathways & $\underline{196}$ & $p g k$ & $\operatorname{lmo} 2458$ & PGK_LISMO & Phosphoglycerate kinase & 3.2 \\
\hline $\begin{array}{l}\text { Metabolism of aminoacids } \\
\text { and related molecules }\end{array}$ & $\underline{13}$ & hom & LMOf6854_2608 & Q4EPH5 & Homoserine dehydrogenase & 2.0 \\
\hline $\begin{array}{l}\text { Metabolism of aminoacids } \\
\text { and related molecules }\end{array}$ & $\underline{41}$ & daaA & $\operatorname{lmo} 1619$ & DAAA_LISMO & D-alanine aminotransferase & 7.3 \\
\hline $\begin{array}{l}\text { Metabolism of coenzymes } \\
\text { and prosthetic groups }\end{array}$ & 57 & thiD & $\operatorname{lmo} 0662$ & Q8Y971 & $\begin{array}{l}\text { Hypothetical protein lmo } 0662 \\
\text { thiamin biosynthetic process }\end{array}$ & 9.9 \\
\hline Regulation & $\underline{31}$ & $\operatorname{ccp} A$ & LMOf6854_1652 & Q4EP90_LISMO & $\begin{array}{l}\text { Catabolite control protein A } \\
\text { (Fragment) }\end{array}$ & 2.7 \\
\hline Protein modification & 56 & & $1 m o 1709$ & Q8Y6H5 & Methionine aminopeptidase & 2.7 \\
\hline
\end{tabular}




\section{Continued}

\begin{tabular}{|c|c|c|c|c|c|c|}
\hline Protein folding & $\underline{4}$ & $d n a K$ & LMOh7858_1570 & Q4EGL2_LISMO & Chaperone protein DnaK & 2.0 \\
\hline $\begin{array}{l}\text { Formate-tetrahydrofolate } \\
\text { ligase activity }\end{array}$ & 11 & fhs & LMOh7858_2002 & Q4EH88_LISMO & Formate-tetrahydrofolate ligase & 3.9 \\
\hline \multicolumn{7}{|c|}{ More abundant proteins in the autolytic strain $\mathrm{C} 897$ at $20^{\circ} \mathrm{C}$ in comparison to $30^{\circ} \mathrm{C}$} \\
\hline Cell wall & 141 & iap & $\operatorname{lmo} 0582$ & Q84DR8_LISMO & Invasion associated protein $\mathrm{p} 60$ & 4.0 \\
\hline Cell wall & 189 & $m b l$ & $\operatorname{lmo} 2525$ & Q8Y4C5_LISMO & $\mathrm{Mbl}$ protein & 2.0 \\
\hline $\begin{array}{l}\text { Transport/binding proteins } \\
\text { and lipoproteins }\end{array}$ & 37 & $\operatorname{man} L$ & LMOf6854_0109 & Q4EUJ0_LISMO & $\begin{array}{l}\text { PTS system, mannose-specific, } \\
\text { IIAB component }\end{array}$ & 2.0 \\
\hline Membrane bioenergetics & 59 & & LMOh7858_2963 & Q4EJS8_LISMO & Oxidoreductase & 2.0 \\
\hline Specific pathways & 267 & $p y k A$ & $\operatorname{lmo} 1570$ & Q8Y6W1_LISMO & Pyruvate kinase & 5.6 \\
\hline Main glycolytic pathways & 2 & $t k t-2$ & LMOf6854_1347 & Q4EPL3_LISMO & Transketolase & 5.7 \\
\hline Main glycolytic pathways & 108 & $p d h A$ & LMOf6854_1104 & Q4ERT5_LISMO & $\begin{array}{l}\text { Pyruvate dehydrogenase complex, E1 } \\
\text { component }\end{array}$ & 2.9 \\
\hline TCA cycle & 22 & $i c d$ & LMOf6854_1617 & Q4EHL3_LISMO & Isocitrate dehydrogenase [NADP] & 2.0 \\
\hline $\begin{array}{l}\text { Metabolism of aminoacids } \\
\text { and related molecules }\end{array}$ & 20 & $\operatorname{gly} A$ & LMOh7858_2691 & Q4EED3_LISMO & Serine hydroxymethyltransferase & 2.0 \\
\hline $\begin{array}{l}\text { Metabolism of aminoacids } \\
\text { and related molecules }\end{array}$ & 21 & $g d h A$ & LMOh7858_0619 & Q4EID3_LISMO & $\begin{array}{l}\text { Glutamate dehydrogenase, } \\
\text { NADP-specific }\end{array}$ & 2.0 \\
\hline $\begin{array}{l}\text { Metabolism of aminoacids } \\
\text { and related molecules }\end{array}$ & 25 & & LMOh7858_1711 & Q4EEZ6_LISMO & $\begin{array}{c}\text { Chorismate } \\
\text { mutase/phospho-2-dehydro-3-deoxyh } \\
\text { eptonate aldolase }\end{array}$ & 2.0 \\
\hline $\begin{array}{l}\text { Metabolism of aminoacids } \\
\text { and related molecules }\end{array}$ & 26 & $\operatorname{trp} B$ & LMOf6854_1683 & Q4EN62_LISMO & Tryptophan synthase, beta subunit & 13.7 \\
\hline $\begin{array}{l}\text { Metabolism of aminoacids } \\
\text { and related molecules }\end{array}$ & 128 & $\operatorname{trp} A$ & LMOf6854_1682 & Q4EN63_LISMO & Tryptophan synthase alpha chain & 2.0 \\
\hline $\begin{array}{l}\text { Metabolism of aminoacids } \\
\text { and related molecules }\end{array}$ & 144 & $\operatorname{aroC}$ & LMOf6854_1987 & Q4EN85_LISMO & Chorismate synthase & 2.8 \\
\hline $\begin{array}{l}\text { Metabolism of aminoacids } \\
\text { and related molecules }\end{array}$ & 233 & & $\operatorname{lmo} 2414$ & Q8Y4M3_LISMO & $\begin{array}{l}\text { Lmo2414 (iron-sulfur cluster } \\
\text { assembly) }\end{array}$ & 3.1 \\
\hline $\begin{array}{l}\text { Metabolism of aminoacids } \\
\text { and related molecules }\end{array}$ & 271 & & LMOf6854_1956 & Q4EQU8_LISMO & Aspartate aminotransferase, putative & 3.1 \\
\hline $\begin{array}{l}\text { Metabolism of nucleotides } \\
\text { and nucleic acids }\end{array}$ & 7 & guaA & LMOh7858_1160 & Q4EKN1_LISMO & GMP synthase & 2.0 \\
\hline $\begin{array}{l}\text { Metabolism of nucleotides } \\
\text { and nucleic acids }\end{array}$ & 63 & pyrE & LMOf2365_1859 & PYRE_LISMF & Orotate phosphoribosyltransferase & 2.0 \\
\hline $\begin{array}{l}\text { Metabolism of nucleotides } \\
\text { and nucleic acids }\end{array}$ & 132 & prs 1 & LMOf6854_0208 & Q4ERM9_LISMO & $\begin{array}{l}\text { Ribose-phosphate } \\
\text { pyrophosphokinase }\end{array}$ & 5.8 \\
\hline $\begin{array}{l}\text { Metabolism of nucleotides } \\
\text { and nucleic acids }\end{array}$ & 149 & purA & LMOh7858_0068 & Q4EK69_LISMO & Adenylosuccinate synthetase & 3.1 \\
\hline $\begin{array}{l}\text { Metabolism of nucleotides } \\
\text { and nucleic acids }\end{array}$ & 268 & pnp & LMOf6854_1374 & Q4ESF0_LISMO & $\begin{array}{l}\text { Polyribonucleotide } \\
\text { nucleotidyltransferase }\end{array}$ & 13.2 \\
\hline Metabolism of lipids & 195 & $f a b D$ & $\operatorname{lmo} 1808$ & Q8Y689_LISMO & $\begin{array}{l}\text { FabD protein (Malonyl CoA-acyl } \\
\text { carrier protein transacylase) }\end{array}$ & 2.0 \\
\hline $\begin{array}{l}\text { Metabolism of coenzymes } \\
\text { and prosthetic groups }\end{array}$ & 139 & $\operatorname{nad} A$ & LMOh7858_2148 & Q4EHC3_LISMO & $\begin{array}{c}\text { Quinolinate synthetase complex, } \\
\text { subunit A }\end{array}$ & 2.0 \\
\hline DNA recombination & 202 & recA & lmo 1398 & RECA_LISMO & Protein RecA & 2.5 \\
\hline Regulation & 60 & & LMOf6854_2133 & Q4EST3_LISMO & $\begin{array}{l}\text { Redox-sensing transcriptional } \\
\text { repressor rex }\end{array}$ & 3.5 \\
\hline Termination & 72 & nus $G$ & LMOh7858_0272 & Q4EDN9_LISMO & $\begin{array}{l}\text { Transcription antitermination } \\
\text { protein nusG }\end{array}$ & 2.2 \\
\hline
\end{tabular}




\section{Continued}

\begin{tabular}{|c|c|c|c|c|c|c|}
\hline Ribosomal proteins & 87 & $r p s F$ & LMOf6854_0054 & Q4EUP5_LISMO & Ribosomal protein S6 & 2.0 \\
\hline Ribosomal proteins & 99 & $r p l U$ & LMOf6854_1590 & Q4EMI9_LISMO & 50 S ribosomal protein L21 & 2.0 \\
\hline Ribosomal proteins & 101 & $r p l Q$ & LMOf6854_2725 & Q4ENX9_LISMO & 50 S ribosomal protein L17 & 3.6 \\
\hline Ribosomal proteins & 102 & rpsE & LMOf6854_2735 & Q4ENW9_LISMO & Ribosomal protein S5 & 3.8 \\
\hline Ribosomal proteins & 106 & rplA & LMOh7858_0275 & Q4EDU9_LISMO & Ribosomal protein L1 & 2.3 \\
\hline Elongation & 1 & fusA & LMOh7858_2915 & Q4EJN0_LISMO & Translation elongation factor $\mathrm{G}$ & 2.0 \\
\hline Detoxification & 69 & sod & LMOf6854_1482 & Q4ETU5_LISMO & Superoxide dismutase & 2.0 \\
\hline Detoxification & 73 & & LMOf6854_1635 & Q4EPZ2_LISMO & Thiol peroxidase & 2.0 \\
\hline Detoxification & 100 & $i s d G$ & LMOf6854_0517 & Q4EVM9_LISMO & $\begin{array}{l}\text { Heme-degrading monooxygenase } \\
\text { isdG }\end{array}$ & 2.4 \\
\hline $\begin{array}{c}\text { Terpenoid biosynthetic } \\
\text { process }\end{array}$ & 61 & & LMOf6854_1139 & Q4EUU3_LISMO & $\begin{array}{l}\text { 2-C-methyl-D-erythritol 4-phosphate } \\
\text { cytidylyltransferase }\end{array}$ & 2.0 \\
\hline GTPase activity & 148 & & LMOf6854_1536 & Q4ETZ9_LISMO & GTPase, putative & 3.9 \\
\hline Cell redox homeostasis & 205 & & LMOf6854_1107 & Q4ERT8_LISMO & Dihydrolipoyl dehydrogenase & 2.7 \\
\hline \multicolumn{7}{|c|}{ More abundant proteins in the non autolytic strain $\mathrm{EGD}$ at $30^{\circ} \mathrm{C}$ in comparison to $\mathrm{C} 897$ at $30^{\circ} \mathrm{C}$} \\
\hline Cell wall & 189 & $m b l$ & $\operatorname{lmo} 2525$ & Q8Y4C5_LISMO & Mbl protein & 2.0 \\
\hline Cell wall & 251 & murC & LMOf6854_1658 & Q4EP84_LISMO & $\begin{array}{c}\text { UDP-N-acetylmuramate-alanine } \\
\text { ligase }\end{array}$ & 3.4 \\
\hline Membrane bioenergetics & 59 & & LMOh7858_2963 & Q4EJS8_LISMO & Oxidoreductase & 3.0 \\
\hline Specific pathways & 38 & $p f k A$ & LMOf2365_1593 & K6PF_LISMF & 6-phosphofructokinase & 2.0 \\
\hline Main glycolytic pathways & 54 & tpiA-2 & LMOh7858_2606 & Q4EEP4_LISMO & Triosephosphate isomerase & 2.0 \\
\hline Main glycolytic pathways & 229 & & LMOf6854_1107 & Q4ERT8_LISMO & $\begin{array}{c}\text { Dihydrolipoyl dehydrogenase, } \\
\text { Pyruvate dehydrogenase complex, } \\
\text { E3 component }\end{array}$ & 2.6 \\
\hline $\begin{array}{l}\text { Metabolism of aminoacids } \\
\text { and related molecules }\end{array}$ & 25 & & LMOh7858_1711 & Q4EEZ6_LISMO & $\begin{array}{c}\text { Chorismate } \\
\text { mutase/phospho-2-dehydro-3-deoxy } \\
\text { heptonate aldolase }\end{array}$ & 2.0 \\
\hline $\begin{array}{l}\text { Metabolism of aminoacids } \\
\text { and related molecules }\end{array}$ & 26 & $\operatorname{trp} B$ & LMOf6854_1683 & Q4EN62_LISMO & Tryptophan synthase, beta subunit & 2.7 \\
\hline $\begin{array}{l}\text { Metabolism of aminoacids } \\
\text { and related molecules }\end{array}$ & 128 & $\operatorname{trp} A$ & LMOf6854_1682 & Q4EN63_LISMO & Tryptophan synthase alpha chain & 2.6 \\
\hline $\begin{array}{l}\text { Metabolism of aminoacids } \\
\text { and related molecules }\end{array}$ & 144 & aroC & LMOf6854_1987 & Q4EN85_LISMO & Chorismate synthase & 2.0 \\
\hline $\begin{array}{l}\text { Metabolism of aminoacids } \\
\text { and related molecules }\end{array}$ & 271 & & LMOf6854_1956 & Q4EQU8_LISMO & Aspartate aminotransferase, putative & 3.7 \\
\hline $\begin{array}{l}\text { Metabolism of nucleotides } \\
\text { and nucleic acids }\end{array}$ & 9 & purH & LMOf6854_1824 & Q4ET64_LISMO & $\begin{array}{c}\text { Phosphoribosylaminoimidazolecar- } \\
\text { boxamide formyltransferase/IMP } \\
\text { cyclohydrolase }\end{array}$ & 2.3 \\
\hline $\begin{array}{l}\text { Metabolism of nucleotides } \\
\text { and nucleic acids }\end{array}$ & 63 & pyrE & LMOf2365_1859 & PYRE_LISMF & Orotate phosphoribosyltransferase & 2.0 \\
\hline $\begin{array}{l}\text { Metabolism of nucleotides } \\
\text { and nucleic acids }\end{array}$ & 160 & purM & LMOf6854_1826 & Q4ET66_LISMO & $\begin{array}{l}\text { Phosphoribosylformylglycinamidine } \\
\text { cyclo-ligase }\end{array}$ & 2.4 \\
\hline
\end{tabular}




\section{Continued}

\begin{tabular}{|c|c|c|c|c|c|c|}
\hline $\begin{array}{l}\text { Metabolism of nucleotides } \\
\text { and nucleic acids }\end{array}$ & 179 & $\operatorname{pur} Q$ & LMOf6854_1829 & Q4ET69_LISMO & $\begin{array}{l}\text { Phosphoribosylformylglycinamidine } \\
\text { synthase I }\end{array}$ & 2.0 \\
\hline Metabolism of lipids & 19 & $f a b F$ & LMOf6854_2265 & Q4EST8_LISMO & $\begin{array}{c}\text { Beta-ketoacyl-acyl carrier protein } \\
\text { synthase II }\end{array}$ & 2.3 \\
\hline Metabolism of lipids & 195 & fabD & $\operatorname{lmo} 1808$ & Q8Y689_LISMO & $\begin{array}{l}\text { FabD protein (Malonyl CoA-acyl } \\
\text { carrier protein transacylase) }\end{array}$ & 3.2 \\
\hline Metabolism of lipids & 23 & ackA2 & LMOf2365_1603 & ACKA2_LISMF & Acetate kinase 2 & 23.9 \\
\hline $\begin{array}{l}\text { Metabolism of coenzymes } \\
\text { and prosthetic groups }\end{array}$ & 42 & panB & $\operatorname{lmo} 1902$ & PANB_LISMO & $\begin{array}{l}\text { 3-methyl-2-oxobutanoate } \\
\text { hydroxymethyltransferase }\end{array}$ & 2.0 \\
\hline $\begin{array}{l}\text { Metabolism of coenzymes } \\
\text { and prosthetic groups }\end{array}$ & 92 & thiD-2 & LMOf6854_0705 & Q4EU28_LISMO & Phosphomethylpyrimidine kinase & 3.3 \\
\hline $\begin{array}{l}\text { Metabolism of coenzymes } \\
\text { and prosthetic groups }\end{array}$ & 139 & $\operatorname{nad} A$ & LMOh7858_2148 & Q4EHC3_LISMO & $\begin{array}{l}\text { Quinolinate synthetase complex, } \\
\text { subunit A }\end{array}$ & 2.0 \\
\hline $\begin{array}{l}\text { Metabolism of coenzymes } \\
\text { and prosthetic groups }\end{array}$ & 167 & $\operatorname{men} B$ & $\operatorname{lmo} 1673$ & Q8Y6L1_LISMO & Naphthoate synthase & 2.2 \\
\hline Regulation & 60 & & LMOf6854_2133 & Q4EST3_LISMO & $\begin{array}{l}\text { Redox-sensing transcriptional } \\
\text { repressor rex }\end{array}$ & 2.0 \\
\hline RNA modification & 84 & & LMOf6854_2430 & Q4ESL7_LISMO & S1 RNA binding domain protein & 2.5 \\
\hline Ribosomal proteins & 15 & & $\operatorname{lmo} 1938$ & Q8Y5W7_LISMO & Lmo1938 protein & 2.0 \\
\hline Ribosomal proteins & 176 & rplA & LMOh7858_0275 & Q4EDU9_LISMO & Ribosomal protein L1 & 2.0 \\
\hline $\begin{array}{l}\text { Terpenoid biosynthetic } \\
\text { process }\end{array}$ & 61 & & LMOf6854_1139 & Q4EUU3_LISMO & $\begin{array}{l}\text { 2-C-methyl-D-erythritol 4-phosphate } \\
\text { cytidylyltransferase }\end{array}$ & 2.0 \\
\hline $\begin{array}{l}\text { Lipopolisacharide } \\
\text { biosynthetic process }\end{array}$ & 64 & $r f b C$ & LMOf6854_1135 & Q4EUT9_LISMO & $\begin{array}{l}\text { DTDP-4-dehydrorhamnose } \\
\text { 3,5-epimerase }\end{array}$ & 2.0 \\
\hline \multicolumn{7}{|c|}{ Proteins only expressed by the non-autolytic strain EGD } \\
\hline Protein modification & 275 & map & LMOf6854_1768 & Q4EMT5_LISMO & Methionine aminopeptidase & NA \\
\hline Translation & 277 & pheT & $\operatorname{lmo} 1607$ & Q8Y6S6_LISMO & PheT protein & NA \\
\hline Quorum-sensing & 280 & $\operatorname{luxS}$ & LMOf6854_1330 & Q4ENQ7_LISMO & $\begin{array}{l}\text { Autoinducer-2 production } \\
\text { protein LuxS }\end{array}$ & NA \\
\hline
\end{tabular}

${ }^{*}$ The functional category is indicated as at ListiList (http://genolist.pasteur.fr/ListiList/); ${ }^{a}$ Fold changes in protein abundance (over-produced) are indicated as the ratio between the normalized spot volume from cells at tested conditions: $\mathrm{C} 897$ at $30^{\circ} \mathrm{C}$ and $20^{\circ} \mathrm{C} ; \mathrm{C} 897$ at $30^{\circ} \mathrm{C}$ and $\mathrm{EGD}$ at $30^{\circ} \mathrm{C} ; \mathrm{C} 897$ at $20^{\circ} \mathrm{C}$ and $\mathrm{C} 897$ at $30^{\circ} \mathrm{C}$; EGD at $30^{\circ} \mathrm{C}$ and $\mathrm{C} 897$ at $30^{\circ} \mathrm{C}$; ${ }^{\text {b }}$ Three spots identified, spot 32,75 and spot 203 ; ; underlined spots are over expressed by $\mathrm{C} 897$ at $30^{\circ} \mathrm{C}$ in comparison to non-autolysis condition at $20^{\circ} \mathrm{C}$ and to $\mathrm{EGD}\left(30^{\circ} \mathrm{C}\right)$. Spots in bold are over-produced both by EGD at $30^{\circ} \mathrm{C}$ and by $\mathrm{C} 897$ at $20^{\circ} \mathrm{C}$.

shock, already has been reported [33,35,39]. Likewise, in another Gram positive bacterium, B. subtilis, the overexpression of Ctc was observed when cells were under osmotic, heat and oxidative stresses and during glucose limitation [40]. Dpr that responds to peroxide stress has been associated with response to lactate exposition in Lactobacillus plantarum [41] and Lactococcus lactis [42] and was reported to protect Streptococcus pyogenes against several stresses [43]. It seems that the Lmo1601 protein (stress protein-like protein) may be involved in the maintenance of the redox balance of the cell because this protein has $59 \%$ similarity to the general stress protein YtxH from B. subtilis. Another over-produced protein worthy of note due to its involvement in stress response is the elongation factor $\mathrm{Tu}(\mathrm{EF}-\mathrm{Tu})$. In Escherichia coli the EF-Tu seems to have a role additional to its translation elongation function, in that it may act as a chaperone-like protein protecting cells from stress [44].
It also has been reported to protect $L$. monocytogenes cells from salt and cold stress [33,35]. None of these proteins have previously been related to autolysis, except DnaK.

The heat shock proteins DnaK and GroEL were overproduced by $\mathrm{C} 897$ at $30^{\circ} \mathrm{C}$ in comparison to $20^{\circ} \mathrm{C}$. The expression of these two proteins is elevated when bacterial cells are exposed to several environmental stress conditions and they play a crucial role in L. monocytogenes in vivo survival $[45,46]$. Besides their recognized value for cell protection under stress, an important role in protein folding has been attributed to GroEL even when bacterial cells grow at optimal temperature [47]. The association of induction of heat shock proteins with autolysis has been reported in $S$. aureus and E. coli $[48,49]$. Recently a dnaK mutant of $S$. aureus was described that showed a reduced autolysis rate in comparison to the wild type strain suggesting a possible role of DnaK on 
autolysins activity [50]. Considering the results obtained by Singh et al. [50] it is tempting to hypothesise that DnaK alone, or in combination with GroEL activate the activity of $\mathrm{P} 60$ and/or P45.

The observation of the over-production of a significant number of stress response proteins by the C897 strain strongly suggests that it is stress that triggers autolysis.

\subsection{The Intracellular Proteome of the Autolytic Strain at Non-Autolysis Condition}

Thirty-night proteins over-expressed at the non-autolysis condition $\left(20^{\circ} \mathrm{C}\right)$ were identified. Data are summarized in the Table 1, Supplementary Table $\mathbf{A}$ and a representative gel is shown in Figures 2(b). These proteins can be distributed among eighteen functional categories. The functional categories that have the highest number of spots are the metabolism of amino acids ( 8 proteins), metabolism of nucleotides and nucleic acids (5 proteins) and ribosomal proteins (6 proteins).

Two oxidative stress proteins were significantly expressed: superoxide dismutase and thiol peroxidase. A component of the SOS response, the activator RecA also was more expressed. The over-production of proteins involved in cell detoxification in non-autolysis and autolysis conditions indicates the higher sensitivity of the autolytic strain to oxidative stress.

At the non-autolysis condition, the intracellular overexpression of the autolysin P60 was observed. This autolysin was at lower levels in the extracellular proteome at $20^{\circ} \mathrm{C}$ (see section 3.7) and thus we can hypothesize that intracellular/extracellular proteome ratio is an important factor in autolysis inhibition.

A significant set of over-produced proteins was also over-produced by the non-autolytic EGD and will be discussed in section 3.5. Intracellular protein expressed in both strains in the absence of autolysis.

\subsection{The Intracellular Proteome of the Non-Autolytic Strain}

Comparison of the intracellular proteomes of the nonautolytic EGD grown in conditions that induce autolysis of C897 can provide information on key elements of the autolysis inhibition process. Twenty-nine proteins that were over-produced in EGD were identified. Data are summarized in Table $\mathbf{1}$ and a representative gel is shown in Figure 2(c). The functional categories with the highest number of spots were the metabolism of amino acids ( 5 proteins), followed by the metabolism of coenzymes and prosthetic groups and the metabolism of nucleotides and nucleic acids (4 proteins) metabolism of lipids and main glycolytic pathways (3 proteins). The five proteins for the metabolism of amino acids and related molecules were common to proteins over-produced by the autolytic

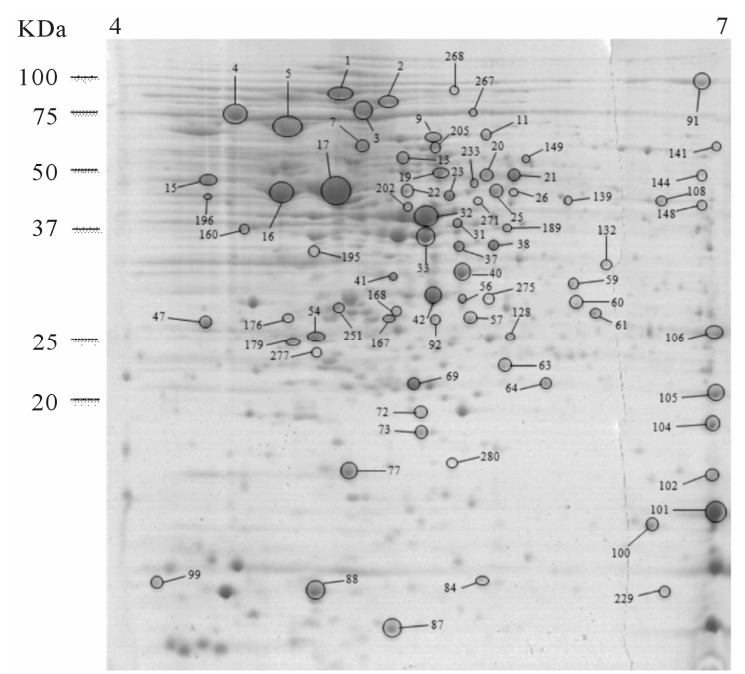

(a)

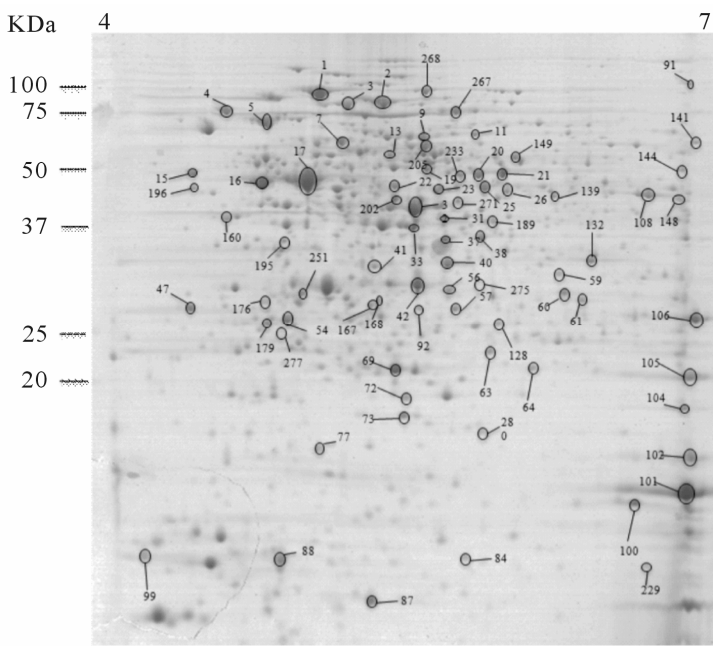

(b)

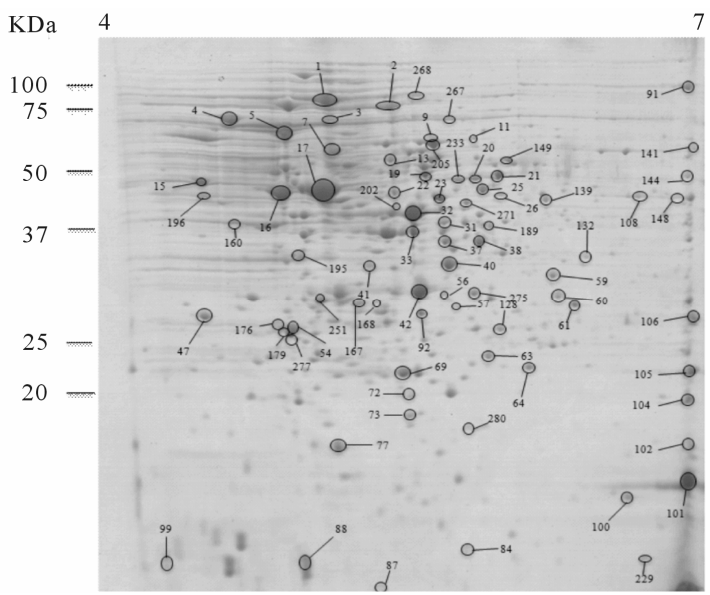

(c)

Figure 2. 2-DE maps of the intracellular proteome of the autolytic strain $\mathrm{C} 897$ grown at $30^{\circ} \mathrm{C}$ (autolysis permissive temperature) (a) at $20^{\circ} \mathrm{C}$ (non-autolysis permissive temperature); (b) and the non-autolytic strain EGD grown at $30^{\circ} \mathrm{C}$; (c) The identified spots are indicated. 
strain at $20^{\circ} \mathrm{C}$ in comparison to $30^{\circ} \mathrm{C}$ (see following section). Two proteins related with the cell wall and one protein related with cell division, Mbl, UDP-N-acetylmuramate alanine ligase and the septum determining protein MinD, respectively were identified. UDP-N-acetylmuramate-alanine ligase (MurC) is one of the fundamental cytoplasmic peptidoglycan biosynthetic enzymes. This enzyme catalyzes the ATP-dependent ligation of L-alanine (Ala) and UDP-N-acetylmuramic acid (UNAM) to form UDP-N-acetylmuramyl-L-alanine (UNAM-Ala). The gene minD belongs to the minicell genetic locus constituted by other two genes $\min C$ and $\min E$ [51]. The investigation of the expression of different combinations of the min genes revealed that $\mathrm{MinC}$ is a division inhibitor and MinD induces MinC activity [51,52]. The possible role of $\mathrm{Mbl}$ will be discussed below, as is a common over produced spot by EGD and the autolytic strain at $20^{\circ} \mathrm{C}$.

The membrane lipid homeostasis and the capacity of bacterial cells to modify the lipid composition according to different environments may dictate bacterial survival. Consistent with the hypothesis that lipid composition influences autolysis, two proteins that are key elements of the fatty acid synthesis ( $\beta$-ketoacyl-acyl carrier protein synthase II (FabF) and the FabD protein, Malonyl CoAacyl carrier protein transacylase) were over-expressed in the non-autolytic strain and in the autolytic strain at $20^{\circ} \mathrm{C}$.

In contrast to over-production of several glycolytic enzymes in $\mathrm{C} 897$ at $30^{\circ} \mathrm{C}$, only two glycolytic proteins were higher in EGD at $30^{\circ} \mathrm{C}$ (6-phosphofructokinase and triosephosphate isomerase). This is consistent with the previous suggestion that the requirement of glycolysis is an important part of the autolysis phenomenon.

The LuxS (S-ribosylhomocysteinase) protein was only found in the intracellular proteome of EGD (Table 1, Supplementary Table A, Figure 2). Autolysis is linked to quorum sensing in $S$. pneumoniae [53,54] which is regulated by the ComDE, which is generally considered to be a component of a quorum sensing mechanism [53]. The participation of quorum-sensing components in $L$. monocytogenes autolysis regulation has not been reported.

\subsection{Intracellular Protein Expressed in Both Strain in the Absence of Autolysis}

Analysis of data collected in the absence of autolysis $\left(\mathrm{C} 897\right.$ at $20^{\circ} \mathrm{C}$ and $\mathrm{EGD}$ at $30^{\circ} \mathrm{C}$ ) revealed a set of common proteins (Table 1, Supplementary Table A). From the 12 identified proteins five are involved in the metabolism of amino acids and two in the metabolism of coenzymes and prosthetic groups. The significance of in- creases in the abundance of proteins associated with the metabolism of the amino acids tyrosine, phenylalanine and tryptophan (chorismate mutase, chorismate synthase, tryptophan synthase, beta and alpha subunits) relies in the role of these aromatic amino acids in the maintenance of the structure and function of membrane proteins [55, 56]. An important clue to the inhibition of autolysis is the component of the cell wall, the Mbl protein (similar to MreB-like protein). Mbl is an isoform of MreB that, together with other proteins, provide a rod shape to bacterial cells. B. subtilis has three MreB isoforms (MreB, $\mathrm{Mbl}$ and $\mathrm{MreBH}$ ) which seems to be responsible for the positioning of peptidoglycan synthases, a peptidoglycan hydrolase (LytE) and other membrane-associated cell morphogenesis proteins, such as MreC and MreD [57]. From these three MreB isoforms, Mre-BH seems to be responsible for the control of the autolytic activity by directing the localization of the cell wall hydrolase LytE [58]. Search of the Listeria genome indicates that only two MreB isoforms are present, the MreB and Mbl. So far the roles of MreB and its $\mathrm{Mbl}$ isoform in L. monocytogenes have not been clarified. From our data it is possible to propose that Mbl plays an important role in autolysis inhibition. The absence of the over-production of the glycolysis enzymes L-lactate dehydrogenase 1 (LDH-1), Lmo 1634 (similar to alcohol dehydrogenase) and glyceraldehyde 3-phosphate dehydrogenase (Gap protein) in the non-autolysis condition may be explained by the over-production of the redox-sensing transcriptional repressor rex (spot 60) which senses the NADH/NAD+ ratio in the cell and which has been shown in Streptomyces coelicolor and Bacillus subtilis to indirectly modulate the metabolism by regulation of genes encoding proteins of the respiratory chain [59,60], whereas in Staph. aureus it regulates the transcription process during the switch from aerobic to anaerobic growth [61]. In Staph. aureus the proteins Adh1, Ldh1 and GapA1 are Rex-regulated, but only Adh1 and Ldh1 have a Rex binding site [61]. The genes regulated by Rex and its role in the aerobic and anaerobic growth of $L$. monocytogenes remains to be clarified.

In both strains at absence of autolysis the 2-C-methylD-erythritol 4-phosphate cytidyltransferase which, is involved in the terpenoid (or isoprenoid) biosynthetic process, was over-produced (Table 1, Supplementary Table A). Isoprenoids include a large number of compounds (more than 30,000) participating in a significant number of physiological processes either in eukaryotes and prokaryotes. In bacteria they have important roles in electron transport chains, with ubiquinone and menaquinone standing out in these roles. Bactoprenols function as carbohydrate carriers in the biosynthesis of peptidoglycan [62, $63]$. 


\subsection{The Extracellular Proteome of the Autolytic Strain at $30^{\circ} \mathrm{C}$ Evidence Over-Production of P60 Family Proteins}

Three spots were identified as being significantly $(\mathrm{P}<$ 0.05 ) more abundant in the culture supernatant of the autolytic strain $\mathrm{C} 897$ when grown at $30^{\circ} \mathrm{C}$, compared to growth at $20^{\circ} \mathrm{C}$. One of them is the autolytic enzyme P60 (invasion associated protein). Data are summarized in the Table 2 and Supplementary Table A and a representative gel is shown in Figure 3(a). Five proteins were identified in the extracellular proteome of the autolytic strain C897 grown at $30^{\circ} \mathrm{C}$ compared to the extracellular proteome of the non-autolytic strain EGD grown at $30^{\circ} \mathrm{C}$. Among them is the P45 autolysin, an amino acid ABC transporter and Lmo1333 which is similar to the B. subtilis YqzC protein (Table 2, Supplementary Table A). P60 was equally abundant in the extracellular proteome of $\mathrm{C} 897$ and $\mathrm{EGD}$ at $30^{\circ} \mathrm{C}$.

The differences in the autolytic behaviour of $\mathrm{C} 897$ at $30^{\circ} \mathrm{C}$ in comparison to the lack of autolysis at $20^{\circ} \mathrm{C}$ could be linked to the higher abundance of P60 in the extracellular proteome of $\mathrm{C} 897$ at $30^{\circ} \mathrm{C}$ whereas the higher abundance of P45 in the extracellular proteome of C897 in comparison to EGD could be linked to the different autolytic behaviour of these two strains.

$\mathrm{P} 60$ is classified as an endo- $\mathrm{N}$-acetylmuramidase [15] and is implicated in cell separation because P60 depletion results on the formation of long chains of cells [14]. The P45 protein displays 55\% similarity and 38\% identity to P60 and also exhibits peptidoglycan hydrolase activity [13]. To date, and in contrast to reported phenotype alterations due to P60 depletion, the exact function of P45 has not been described. As these two autolysins were detected in higher quantities in the extracellular proteome of the autolytic strain at $30^{\circ} \mathrm{C}$, in comparison to the growth conditions in absence of autolysis (P60 linked to temperature and P45 linked to strain) become evident their impact on the autolysis process.

\subsection{The Extracellular Proteome at Non-Autolysis Conditions (Temperature and Strain)}

The analysis of the extracellular proteome at non-autolysis condition was done by collecting the supernatant of EGD at $30^{\circ} \mathrm{C}$ and $\mathrm{C} 897$ at $20^{\circ} \mathrm{C}$ at the end of exponential phase (an approximate $\mathrm{OD}_{600 \mathrm{~nm}}$ of 0.5 - 0.6, Figures 1(a) and (b)). Seven extracellular proteins of the autolytic strain were identified as being expressed only at the nonautolytic condition $\left(20^{\circ} \mathrm{C}\right)$, (Table 2, Supplementary Table A and Figure 3(b)) and only two proteins belong to the same functional category (metabolism of nucleotides and nucleic acids). Among the eight proteins, a cell surface

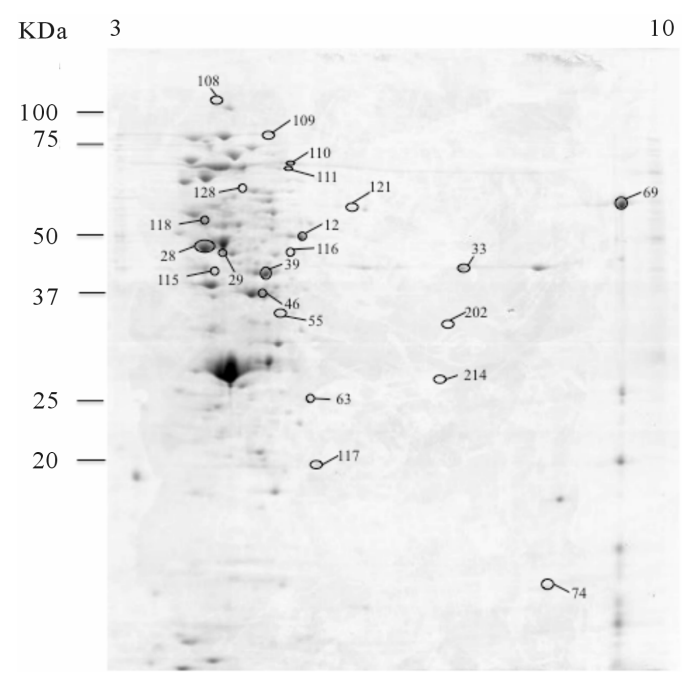

(a)

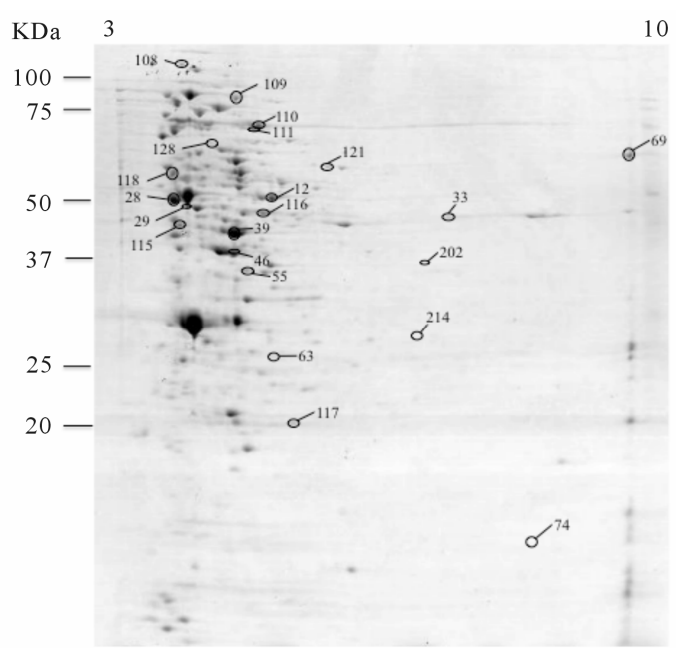

(b)

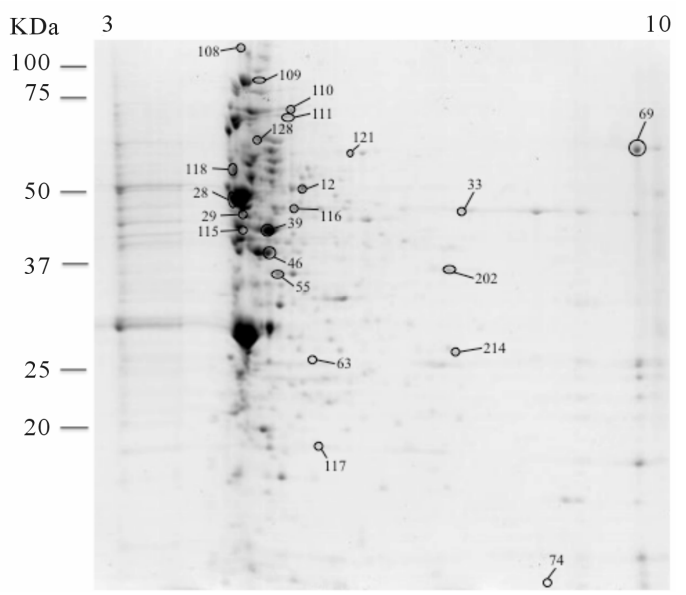

(c)

Figure 3. 2-DE maps of the extracellular proteome of the autolytic strain $\mathrm{C} 897$ grown at $30^{\circ} \mathrm{C}$ (autolysis permissive temperature) (a) at $20^{\circ} \mathrm{C}$ (non-autolysis permissive temperature); (b) and the non-autolytic strain EGD grown at $30^{\circ} \mathrm{C}$; (c) The identified spots are indicated. 
protein (Lmo2185, SvpA, NEAr transporter) and a protein related with bioenergetics, an ATP synthase, were identified. The production of SvpA protein increases significantly when cells experience iron deprivation and studies on cellular fractions showed that in iron-rich media SvpA is entirely secreted into the culture supernatant
[64]. The comparison of the extracellular proteome of $\mathrm{C} 897$ and $\mathrm{EGD}$ at $30^{\circ} \mathrm{C}$ showed five over-expressed proteins of the extracellular proteome of the non-autolytic strain, EGD (Table 2, Supplementary Table A and Figure 3(c)). One of these spots belongs to the transport/ binding lipoproteins and is an EII Mant PTS permease

Table 2. Proteins identified in the extracellular proteome of C897 and EGD strain.

\begin{tabular}{|c|c|c|c|c|c|}
\hline Functional category or description ${ }^{*}$ & Spot ID & Gene/Locus name & Uniprot ID & Uniprot protein name & Fold Change ${ }^{a}$ \\
\hline \multicolumn{6}{|c|}{ More abundant proteins secreted by the autolytic strain $\mathrm{C} 897$ at $30^{\circ} \mathrm{C}$ in comparison to the non autolysis condition $\left(20^{\circ} \mathrm{C}\right)$} \\
\hline Cell wall & 69 & iap/LMOf2365_0611 & Q722W8 & Invasion associated protein P60 & 2.5 \\
\hline Transport/binding proteins and lipoproteins & 63 & LMOf2365_2319 & Q71X80 & Amino acid $\mathrm{ABC}$ transporter & 2.0 \\
\hline Main glycolitic pathways & 29 & $p g k / \mathrm{mo} 2458$ & Q8Y4I2 & Phosphoglycerate kinase & 23.7 \\
\hline \multicolumn{6}{|c|}{ More abundant proteins secreted by the autolytic strain $\mathrm{C} 897$ at $30^{\circ} \mathrm{C}$ in comparison to the non autolytic strain EGD at $30^{\circ} \mathrm{C}$} \\
\hline Cell wall & $33^{\mathrm{b}}$ & spl/1mo2505 & Q9RE04 & Peptidoglycan lytic protein P45 & 3.7 \\
\hline $\begin{array}{c}\text { Metabolism of amino acids and related } \\
\text { molecules }\end{array}$ & 12 & $\operatorname{lmo} 0560$ & Q8Y9G8 & $\begin{array}{l}\text { Lmo0560 protein, similar to } \\
\text { NADP-specific glutamate } \\
\text { dehydrogenase }\end{array}$ & 2.0 \\
\hline Metabolism of nucleotides and nucleic acids & 121 & guaB/lin2901 & Q7ANT6 & $\begin{array}{l}\text { Similar to inosine-monophosphate } \\
\text { dehydrogenase }\end{array}$ & 2.2 \\
\hline Specific pathways & 110 & pykA/lmo1570 & Q8Y6W1 & Pyruvate kinase & 4.23 \\
\hline $\begin{array}{l}\text { From other organisms } \\
\text { (Regulation and sensing) }\end{array}$ & 74 & $\operatorname{lmo} 1333$ & Q8Y7E9 & $\begin{array}{l}\text { Lmo1333, similar to B. subtilis } \\
\text { YqzC protein }\end{array}$ & 2.2 \\
\hline \multicolumn{6}{|c|}{ More abundant proteins secreted by the non-autolytic strain EGD at $30^{\circ} \mathrm{C}$ in comparison to the autolytic strain EGD at $30^{\circ} \mathrm{C}$} \\
\hline Cell wall & 46 & $m r e B / 1 m o 1548$ & Q8Y6Y3 & MreB protein & 4.5 \\
\hline $\begin{array}{c}\text { Transport/binding proteins and } \\
\text { lipoproteins }\end{array}$ & 55 & $m p t A / 1 m o 0096$ & Q8YAM2 & $\begin{array}{l}\text { EIIMant PTS permease IIAB } \\
\text { subunit }\end{array}$ & 3.0 \\
\hline Main glycolytic pathways & 28 & eno/lin2549 & P64075 & $\begin{array}{l}\text { Hypothetical protein lin2549 } \\
\text { (enolase) }\end{array}$ & 5.6 \\
\hline Main glycolytic pathways & 39 & gap/lmo2459 & Q8Y4I1 & $\begin{array}{l}\text { Glyceraldehyde-3-phosphate } \\
\text { dehydrogenase }\end{array}$ & 2.0 \\
\hline Main glycolytic pathways & 128 & gpmI/lmo2456 & Q8Y4I4 & Phosphoglyceratemutase & 13.0 \\
\hline \multicolumn{6}{|c|}{ Proteins only detected in the extracellular proteome of the autolytic strain $\mathrm{C} 897$ at $20^{\circ} \mathrm{C}$} \\
\hline Membrane bioenergetics & 118 & atpD2/1mo2529 & Q8Y4C1 & ATP synthase subunit beta 2 & NA \\
\hline Cell surface proteins & 111 & $\operatorname{lmo} 2185$ & Q9KGV9 & $\begin{array}{l}\text { Lmo2185 protein } \\
\text { (SvpA, P64 protein) }\end{array}$ & NA \\
\hline $\begin{array}{l}\text { Metabolism of amino acids and related } \\
\text { molecules }\end{array}$ & 116 & lwe1614 & A0AJ50 & Chorismate mutase & NA \\
\hline Metabolism of nucleotides and nucleic acids & 108 & $\operatorname{carB} / \mathrm{lmo} 1835$ & Q8Y665 & $\begin{array}{c}\text { Carbamoyl-phosphate synthase } \\
\text { large chain }\end{array}$ & NA \\
\hline Metabolism of nucleotides and nucleic acids & 109 & pnp/lmo1331 & Q8Y7F1 & $\begin{array}{l}\text { Polyribonucleotide } \\
\text { nucleotidyltransferase }\end{array}$ & NA \\
\hline Elongation & 115 & rроA/lin 2755 & P66700 & $\begin{array}{l}\text { DNA-directed RNA polymerase } \\
\text { subunit alpha }\end{array}$ & NA \\
\hline Ribosomal proteins & 117 & rplF/mo2617 & Q8Y444 & 50 S ribosomal protein $\mathrm{L} 6$ & NA \\
\hline \multicolumn{6}{|c|}{ Proteins detected only in the secretome of the non-autolytic strain EGD at $30^{\circ} \mathrm{C}$} \\
\hline Transport/binding proteins and lipoproteins & 202 & $\operatorname{lmo} 2192$ & Q8Y581 & $\begin{array}{l}\text { Lmo2192 protein, similar to } \\
\text { oligopeptide } A B C \text { transporter }\end{array}$ & NA \\
\hline $\begin{array}{c}\text { Metabolism of coenzymes and prosthetic } \\
\text { groups }\end{array}$ & 214 & nadC/lmo2024 & Q8Y5N3 & $\begin{array}{l}\text { NadC protein, similar to } \\
\text { nicotinate-nucleotide } \\
\text { pyrophosphorylase }\end{array}$ & NA \\
\hline
\end{tabular}

"The functional category is indicated as at ListiList (http://genolist.pasteur.fr/ListiList/); ${ }^{a}$ Fold changes in protein abundance (over-produced) in the secretome are indicated as the ratio between the normalized spot volume from cells at tested conditions: $\mathrm{C} 897$ at $30^{\circ} \mathrm{C}$ and $20^{\circ} \mathrm{C} ; \mathrm{C} 897$ at $30^{\circ} \mathrm{C}$ and $\mathrm{EGD}$ at $30^{\circ} \mathrm{C}$; EGD at $30^{\circ} \mathrm{C}$ and $\mathrm{C} 897$ at $30^{\circ} \mathrm{C}$; ${ }^{\mathrm{b}} \mathrm{T}$ wo spots identified, spot 33 and spot 34 . 
IIAB subunit. An increase expression of this mannosespecific PTS enzyme IIAB also was detected in the intracellular proteome of L. monocytogenes LO28 when the bacterial cells were exposed to salt stress and this increase may be related to higher energy requirements [33].

\section{Conclusions}

Our results show that at the end of exponential phase the autolytic strain increases the production of a series of proteins with a recognized role in combating the action of environmental stressors. This does not occur with the non-autolytic EGD and suggest that C897 is more sensitive to stresses that eventually can trigger the autolysis process. At the autolysis permissive temperature $\left(30^{\circ} \mathrm{C}\right)$ the secretion of two autolysins (P60 and P45) was greater than at the non-autolysis permissive temperature $\left(20^{\circ} \mathrm{C}\right)$ and by the non-autolytic strain EGD. On other hand increased amounts of the P60 autolysin was observed in the intracellular proteome at non-permissive temperature. These findings suggest that at lower temperature the export of autolysins is inhibited and this may be due to alterations in the cell wall as evidenced by the over-production of proteins involved in cell wall synthesis. Differences in over-produced proteins of the glycolytic pathway, fatty acid and amino acids synthesis, transcription regulation, cell wall synthesis and morphogenesis are elements that may assure the less susceptible profile of EGD to autolysis. A significant number of proteins related to fatty acid and amino acid synthesis, transcription regulation and cell morphogenesis were commonly over-produced by the non-autolytic strain EGD and by the autolytic strain at autolysis non-permissive temperature, indicating a set of important cellular events important to the lack of autolysis.

From the collected data the cell shape Mbl protein and the transcriptional repressor Rex can constitute possible cell targets to trigger autolysis.

\section{Acknowledgements}

This work was supported by Fundação para a Ciência e a Tecnologia (PTDC/AGRI-ALI/2006 and IBB/CBME, LA, FEDER/POCI). ML Faleiro is grateful for the grant SFRH/BSAB/859/2008.

\section{REFERENCES}

[1] E. Jones, G. Shama, D. Jones, I. S. Roberts and P. A. Andrew, "Physiological and Biochemical Studies on Phychrotolerance in Listeria monocytogenes," Journal of Applied Microbiology, Vol. 83. No. 1, 1997, pp. 31-35. doi:10.1046/j.1365-2672.1997.d01-391.x

[2] L. Pine, G. B. Malcom, J. B. Brooks and M. I Danesshvar, "Physiological Studies on the Growth and Utilization of
Sugars by Listeria Species," Canadian Journal of Microbiology, Vol. 35, No. 2, 1989, pp. 245-254.

doi: $10.1139 / \mathrm{m} 89-037$

[3] J. V. Holtje, "From Growth to Autolysis: The Murein Hydrolases in Escherichia coli," Archives of Microbiology, Vol. 164, No. 4, 1995, pp. 243-254. doi:10.1007/BF02529958

[4] A. M. Berry, R. A. Lock, D. Hansman and J. C. Paton, "Contribution of Autolysin to Virulence of Streptococcus pneumoniae," Infection and Immunity, Vol. 57, No. 8, 1989, pp. 2324-2330.

[5] N. Mani, L. M. Baddour, D. Q. Offutt, U. Vijaranakul, M. J. Nadakavukaren and R. K. Jayaswal, "Autolysis-Defective Mutant of Staphylococcus aureus: Pathological Considerations, Genetic Mapping and Electron Microscopic Studies," Infection and Immunity, Vol. 62, No. 4, 1994, pp. 1406-1409.

[6] E. A. Marcus and D. R. Scott, "Cell Lysis Is Responsible for the Appearance of Extracellular Urease in Helicobacter pylori," Helicobacter, Vol. 6, No. 2, 2001, pp. 93-99. doi:10.1046/j.1523-5378.2001.00014.x

[7] A. Bubert, M. Kuhn, W. Goebel and S. Kohler, "Structural and Functional Properties of the p60 Proteins from Different Listeria Species," Journal of Bacteriology, Vol. 174, No. 24, 1992, pp. 8166-8171.

[8] D. Cabanes, O. Dussurget, P. Dehoux and P. Cossart, "Auto, a Surface Associated Autolysin of Listeria monocytogenes Required for Entry into Eukaryotic cells and Virulence," Molecular Microbiology, Vol. 51, No. 6, 2004, pp. 1601-1614. doi:10.1111/j.1365-2958.2003.03945

[9] S. A Carroll, T. Hain, U. Technow, A. Darji, P. Phashalidis, S. W. Joseph and T. Chakraborty, "Identification and Characterization of a Murein Hydrolase, MurA, of Listeria monocytogenes, a Muramidase Needed for Cell Separation," Journal of Bacteriology, Vol. 185, No. 23, 2003, pp. 6801-6808. doi:10.1128/JB.185.23.6801-6808.2003

[10] A. M McLaughlan and S. J. Foster, "Molecular Characterization of an Autolytic Amidase of Listeria monocytogenes EGD," Microbiology, Vol. 144, No. Pt 5, 1998, pp. 1359-1367.

[11] E. Milohanic, R. Jonquieres and P. B. Coossart, "The Autolysin Ami Contributes to the Adhesion of Listeria monocytogenes to Eukaryotic Cells via Its Cell wall Anchor," Molecular Microbiology, Vol. 39, No. 5, 2001, pp. 1212- 1224. doi:10.1111/j.1365-2958.2001.02208.x

[12] M. Popowska and Z. Markiewicz,"Characterization of Listeria monocytogenes Protein Lmo0327 with Murein Hydrolase Activity," Archives of Microbiology, Vol. 186, No. 1, 2006, pp. 69-86. doi:10.1007/s2003-006-0122-8

[13] K. Schubert, A. M. Bichlmaier, E. Mager, K. Wolff, G. Ruhland and F. Fiedler, "P45, an Extracellular $45 \mathrm{kDa}$ Protein of Listeria monocytogenes with Similarity to Protein p60 and Exhibiting Peptidoglycan Lytic Activity," Archives of Microbiology, Vol. 173, No. 1, 2000, pp. 21-28. doi:10.1007/s20030050003

[14] S. Pilgrim, A. Kolb-Mäurer, I. Gentshev, W. Goebel and M. Kuhn, "Deletion of the Gene Encoding p60 in Listeria monocytogenes Leads to Abnormal Cell Division and Loss 
of Actin-Based Motility," Infection and Immunity, Vol. 71, No. 6, 2003, pp. 3473-3484. doi:10.1128/IAI.71.6.3473-3484.2003

[15] M. D. Wuenscher, S. Köhler, A. Bubert, U. Gerike and W. Goebel, "The iap Gene of Listeria monocytogenes Is Essential for Cell Viability, and Its Gene Product, p60, Has Bacteriolytic Activity," Journal of Bacteriology, Vol. 175, No. 11, 1993, pp. 3491-350.

[16] R. Gonzalez, A. J. Martinez-Rodriguez and A. V. Carrascosa, "Yeast Autolytic Mutants Potentially Useful for Sparking Wine Production," International Journal of Food Microbiology, Vol. 84, No. 1, 2003, pp. 21-26. doi:1016/S0168-1605(02)00389-6

[17] T. Emri, Z. Molnár, M. Szilágyi and I. Pócsi, "Regulation of Autolysis in Aspergillus nidulans," Applied Biochemistry and Biotechnology, Vol. 151, No. 2-3, 2008, pp. 211220. doi:10.1007/s12010-008-8174-7

[18] F. C. Neuhaus and J. Baddiley, "A Continuum of Anionic Charge: Structures and Functions of D-Alanyl-teichoic Acids in Gram-Positive Bacteria," Microbiology and Molecular Biology, Vol. 67, No. 4, 2003, pp. 686-723. doi:10.1128.MMBR.67.4.686-723.2003

[19] I. Fedtke, D. Mader, T. Kohler, H. Moll, G. Nicholson, R. Biswas, K. Henseler, F. Götz, U. Zähringer and A. Peschel, "A Staphylococcus aureus ypfP Mutant with Strongly Reduced Lipoteichoic Acid (LTA) Content: LTA Governs Bacterial Surface Properties and Autolysin Activity," Molecular Microbiology, Vol. 65, No. 4, 2007, pp. 10781091. doi:10.1111/j.1365-2958.2007.05854.x

[20] J. R.Scott and T. C. Barnett, "Surface Proteins of GramPositive Bacteria and How They Get There," Annual Reviews of Microbiology, Vol. 60, 2006, pp. 397-423. doi:10.1146/annurev.micro.60.080805.142256

[21] J. Wecke, K Madela and W. Fischer, "The Absence of DAlanine from Lipoteichoic Acid and Wall Teichoic Acid Alters Surface Charge, Enhances Autolysis and Increases Susceptibility to Methicillin in Bacillus subtilis," Microbiology, Vol. 143, No. 9, 1997, pp. 2953-2960. doi:10.1099/00221287-143-9-2953

[22] S. Mesnage, T. Fontaine, M. Mignot, M. Delepierre, M. Mock and A. Fouet, "Bacterial SLH Domain Proteins Are Non-Covalently Anchored to the Cell Surface via a Conserved Mechanism Involving Wall Polysaccharide Pyruvylation," The EMBO Journal, Vol. 19, No. 17, 2000, pp. 4473-4484. doi:10.1093/emboj/19.17.4473

[23] L. O. Ingram, "Mechanism of lysis of Escherichia coli by Ethanol and other Chaotropic Agents," Journal of Bacteriology, Vol. 146, No. 1, 1981, pp. 331-336.

[24] S. R. Watt and A. J. Clarke, "Role of Autolysins in the EDTA-Induced Lysis of Pseudomonas aeruginosa," FEMS Microbiology Letters, Vol. 124, No. 1, 1994, pp. 113-120. doi:10.1111/j.1574-6968.1994.tb07270.x

[25] T. Ochiai, "Salt-Sensitive Growth of Staphylococcus aureus: Stimulation of Salt-Induced Autolysis by Multiple Environmental Factors," Microbiology and Immunology, Vol. 43, No. 7, 1999, pp. 705-709.

[26] T. L. Trivett and E. A Meyer, "Citrate Cycle and Related Metabolism of Listeria monocytogenes," Journal of Bacteriology, Vol. 107, No. 3, 1971, pp. 770-779.
[27] A. Adrião, M. Vieira, I. Fernandes, M. Barbosa, M. Sol, R. P. Tenreiro, L. Chambel, B. Barata, I. Zilhão, G. Shama, S. Perni, S. J. Jordan, P. W. Andrew and M. L. Faleiro, "Marked Intra-Strain Variation in Response of Listeria monocytogenes Dairy Isolates to Acid or Salt Stress and the Effect of Acid or Salt Adaptation on Adherence to Abiotic Surfaces," International Journal of Food Microbiology, Vol. 123, 2008, pp. 142-150. doi:10.1016/i.ijfoodmicro.2007.12.016

[28] M. L.Faleiro, P. W. Andrew and D. Power, "Stress Response of Listeria monocytogenes Isolated from Cheese and other Foods," International Journal of Food Microbiology, Vol. 84, No. 2, 2003, pp. 207-216. doi:10.1016/S0168-1605(02)00422-1

[29] R. Fontana, M. Boaretti, A. Grossato, E. A. Tonin, M. M. Lléo and G. Satta, "Paradoxical Response of Enterococcus faecalis to the Bactericidal Activity of Penicillin is Associated with Reduced Activity of one Autolysin," Antimicrobial Agents and Chemotherapy, Vol. 34, No. 2, 1990, pp. 314-320.

[30] C.-Y. Chen, G. W. Nace and P. L. Irwin, "A $6 \times 6$ Drop Plate Method for Simultaneous Colony Counting and MPN Enumeration of Campylobacter jejuni, Listeria monocytogenes and Escherichia coli," Journal of Microbiological Methods, Vol. 55, No. 2, 2003, pp. 475-479. doi:10.1016/S0167-7012(03)00194-5

[31] M. Trost, D. Wehmhöner, U. Kärst, G. Dieterich, J. Wehland and L. Jänsch, "Comparative Proteome Analysis of Secretory Proteins from Pathogenic and Non-Pathogenic Listeria Species," Proteomics, Vol. 5, No. 6, 2005, pp. 1544-1557. doi:10.1002/pmic.200401024

[32] P. Folio, P. Chavant, I. Chafsey, A. Belkorchia, C. Chambon and M. Hébraud, "Two-Dimensional Electrophoresis Database of Listeria monocytogenes EGDe Proteome and Proteomic Analysis of Mild-Log and Stationary Growth Phase Cells," Proteomics, Vol. 4, 2004, pp. 3187-3201. doi:10.1002/pmic.200300841

[33] O. Duché, F. Tremoulet, P. Glaser and J. Labadie, "Salt Stress Proteins Induced in Listeria monocytogenes," Applied and Environmental Microbiology, Vol. 68, No. 4, 2002, pp. 1491-1498. doi:10.1128/AEM.68.4.1491-1498.2002

[34] C. Castaldo, R. A. Siciliano, L. Muscariello, R. Marasco and M. Sacco, "CcpA Affects Expression of the groESL and dnaK operons in Lactobacillus plantarum," Microbial Cell Factories, Vol. 5, 2006, p. 35. doi:10.1186/1475-2859-5-35

[35] G. Cacace, M. F. Mazzeo, A. Sorrentino, V. Spada, A. Malorni and R. A Siciliano, "Proteomics for the Elucidation of Cold Adaptation Mechanisms in Listeria monocytogenes," Journal of Proteomics, Vol. 73, No. 10, 2010, pp. 2021-2030. doi:10.1016/j.prot.2010.06.011

[36] H. Antelmann, J. Bernhardt, R. Schmid, H. Mach, U. Völker and M. Hecker, "First Steps from a Two-Dimensional Protein Index towards a Response-Regulation Map for Bacillus subtilis," Electrophoresis, Vol. 18, No. 8, 1997, pp. 1451-1463. doi:10.1002/elps.1150180820

[37] P. Graumann, K. Schröder, R. Schmid and M. A Marahiel, "Cold Shock Stress-Induced Proteins in Bacillus subtilis," 
Journal of Bacteriology, Vol. 178, No. 15, 1996, pp. 46114619.

[38] R. J. Thompson, H. G. A. Bouwer, D. A. Portnoy and F. R. Frankel, "Pathogenicity and Immunogenicity of a Listeria monocytogenes Strain that Requires D-Alanine for Growth," Infection and Immunity, Vol. 66, No. 8, 1998, pp. 3552-3561.

[39] R. Gardan, O. Duché, S. Leroy-Sétrin, European Listeria Genome Consortium and J. Labadie, "Role of ctc from Listeria monocytogenes in Osmotolerance," Applied and Environmental Microbiology, Vol. 69, No. 1, 2003, pp. 154-161. doi:10.1128/AEM.69.1.154-161.2003

[40] U. Völker, S. Engelmann, B. Maul, S. Riethdorf, A. Völker, R. Schmid, H. Mach and M. Hecker, "Analysis of the Induction of General Stress Proteins of Bacillus subtilis," Microbiology, Vol. 140, No. Pt 4, 1994, pp. 741-52. doi:10.1099/00221287-140-4-741

[41] B. Pieterse, J. Rob, R. J. Leer, F. H. J. Schuren and M. J. van der Werf, "Unravelling the Multiple Effects of Lactic acid stress on Lactobacillus plantarum by Transcription Profiling," Microbiology, Vol. 151, No. Pt12, 2005, pp. 3881-3894. doi:10.1099/mic.0.28304-0

[42] A. Hartke, S. Bouché, J-C. Giard, A. Benachour, P. Boutibonnes and Y. Auffray, "The Lactic Acid Stress Response of Lactococcus lactis subsp. lactis," Current Microbiology, Vol. 33, No. 3, 1996, pp. 194-199. doi:10.1007/s002849900099

[43] C.-C. Tsou, C. Chiang-Ni, Y.-S. Lin, W.-J. Chuang, M. T. Lin, C. C. Liu and J. J. Wu, "An Iron-Binding Protein, Dpr, Decreases Hydrogen Peroxide Stress and Protects Streptococcus pyogenes Against Multiple Stresses," Infection and Immunity, Vol. 76, No. 9, 2008, pp. 40384045. doi:10.1128/IAI.00477-08

[44] T. D. Caldas, A. E. Yaagoubi and G. Richarme, "Chaperone Properties of Bacterial Elongation Factor EF-Tu," The Journal of Biological Chemistry, Vol. 273, No. 19, 1998, pp. 11478-11482. doi:10.1074/jbc.273.19.11478

[45] T. Hanawa, M. Fukuda, H. Kawakami, H. Hirano, S. Kamiya and T. Yamamoto, "The Listeria monocytogenes DnaK Chaperone Is Required for Stress Tolerance and Efficient Phagocytosis with Macrophages," Cell Stress Chaperones, Vol. 4, No. 2, 1999, pp. 118-128.

[46] C. G. M.Gahan, J. O’Mahony and C. Hill, "Characterization of the groESL Operon in Listeria monocytogenes: Utilization of Two Reporter Systems (gfp and hly) for Evaluating in Vivo Expression," Infection and Immunity, Vol. 69, No. 6, 2001, pp. 3924-3932. doi:10.1128/IAI.69.6.3924-3932.2001

[47] O. Fayet, T. Ziegelhoffer and C. Georgopoulos, "The groES and groEL Heat Shock Gene Products of Escherichia coli Are Essential for Bacterial Growth at All Temperatures," Journal of Bacteriology, Vol. 171, No. 3, 1989, pp. 1379-1385.

[48] M. W. Qoronfleh, J. E. Gustafson and B. J. Wilkinson, "Conditions that Induce Staphylococcus aureus Heat Shock Proteins also Inhibit Autolysis," FEMS Microbiology Letters, Vol. 66, No. 1, 1998, pp. 103-107. doi:10.1111/j.1574-6968.1998.tb13189.x
[49] J. K. Powell and K. Y. Young, "Lysis of Escherichia coli by Beta-Lactams which bind Penicillin-Binding Proteins 1a and 1b: Inhibition by Heat Shock Proteins," Journal of Bacteriology, Vol. 173, No. 13, 1991, pp. 4021-4026.

[50] V. K. Singh, S. Utaida, L. S. Jackson, R. K. Jayaswal, B. J. Wilkinson and N. R. Chamberlain, "Role of dnaK locus in Tolerance of Multiple Stresses in Staphylococcus aureus," Microbiology, Vol. 153, No. 9, 2007, pp. 31623173. doi:10.1099/mic.0.2007/009506-0

[51] P. A. J. de Boer, R. E. Crossley and L. I. Rothfield, "Central Role for the Escherichia coli minC Gene Product in Two Different Cell Division-Inhibition Systems," Proceedings of the National Academy of Sciences of USA, Vol. 87, No. 3, 1990, pp. 1129-1133. doi:10.1073/pnas.87.3.1129

[52] P. A. J. de Boer, R. E. Crossley and L. I. Rothfield, “A Division Inhibitor and a Topological Specificity Factor Coded for by the Minicell Locus Determine Proper Placement of the Division Septum in E. coli," Cell, Vol. 56, No. 4, 1989, pp. 641-649. doi:10.1016/0092-8674(89)90586-2

[53] J. P. Claverys, M. Prudhomme and B. Martin, "Induction of Competence Regulons as General Stress Responses in Gram-positive Bacteria," Annual Reviews in Microbiology, Vol. 60, 2006, pp. 451-475. doi:10.1146/annurev.micro.60.080805.142139

[54] G. E. Piñas, P. R. Cortes, A. G. A. Orio and J. Echenique, "Acidic Stress Induces Autolysis by a CSP-Independent ComE Pathway in Streptococcus pneumoniae," Microbiology, Vol. 154, No. Pt 5, 2008, pp. 1300-1308. doi:10.1099/mic.0.2007/015925-0

[55] R. R. Draheim, A. F. Bormans, R. Z. Lai and M. D. Manson, "Tryptophan Residues Flanking the Second Transmembrane helix (TM2) Set the Signalling State of the Tar Chemoreceptor," Biochemistry, Vol. 44, No. 4, 2005, pp. 1268-1277. doi:10.1021/bi048969d

[56] A. S. Miller and J. J. Falke, "Side Chains at the Membrane-Water Interface Modulate the Signalling State of a Transmembrane Receptor," Biochemistry, Vol. 43, No. 7, 2004, pp. 1763-1770. doi:10.1021/bi0360206

[57] R. Carballido-López and A. Formstone, "Shape Determination in Bacillus subtilis," Current Opinion in Microbiology, Vol. 10, 2007, pp. 611-616. doi:10.1016/j.mib.2007.09.008

[58] R. Carballido-López and A. Formstone, Y. Li, S. D. Herlich, P. Noirot and J. Errington, “Actin Homolog MreBH Governs Cell Morphogenesis by Localization of the Cell Wall Hydrolase LytE," Developmental Cell, Vol. 11, No. 3, 2006, pp. 399-409. doi:10.1016/j.devcel.2006.07.017

[59] D. Brekasis and M. Paget, "A Novel Sensor of NADH/ NAD Redox Poise in Streptomyces coelicolor A3(2)," The EMBO Journal, Vol. 22, No. 18, 2003, pp. 4856-4865. doi:10.1093/emboj/cdg453

[60] M. Schau, Y. Chen and F. M. Hulett, "Bacillus subtilis YdiH Is a Direct Negative Regulator of the cydABCD Operon," Journal of Bacteriology, Vol. 186, No. 14, 2004, pp. 4585-4595. doi:10.1128/JB.186.14.4585-4595.2004

[61] M. Pagels, S. Fuchs, J. Pané-Farré, C. Kohler, L. Men- 
schner, M. Hecker, P. J. McNamarra, M. C. Bauer, C. von Wachenfeldt, M. Liebeke, M. Lalk, G. Sander, C. von Eiff, R. A. Proctor and S. Engelmann, "Redox Sensing by a Rex-family Repressor Is Involved in the Regulation of Anaerobic Gene Expression in Staphylococcus aureus," Molecular Microbiology, Vol. 76, No. 5, 2010, pp. 11421161. doi:10.1111/j.1365-2958.2010.07105.x

[62] Y. Boucher and W. F. Doolittle, "The Role of Lateral Gene Transfer in the Evolution of Isoprenoid Biosynthesis Pathways," Molecular Microbiology, Vol. 37, No. 4, 2000, pp. 703-716.

doi:10.1046/j.1365-2958.2000.02004.x
[63] R. S. Putra, A. Disch, J. M. Bravo and M. Rohmer, "Distribution of Mevalonate and Glyceraldehyde 3-Phosphate/ Pyruvate Routes for Isoprenoid Biosynthesis in some Gram-Negative Bacteria and Mycobacteria," FEMS Microbiology Letters, Vol. 164, No. 1, 1998, pp. 169-175. doi:10.1111/j.1574-6968.1998.tb13082.x

[64] S. M. C. Newton, P. E. Klebba, C. Raynaud, Y. Shao, X. Jiang, I. Dubail, C. Archer, C. Frehel and A. Charbit, "The svpA-srtB Locus of Listeria monocytogenes: Furmediated Iron Regulation and Effect on Virulence," Molecular Microbiology, Vol. 55, No. 3, 2005, pp. 927-940. doi:10.1111/j.1365-2958.2004.04436.x 
Supplementary Table A. Identification of proteins differentially expressed under autolysis and non-autolysis condition.

\begin{tabular}{|c|c|c|c|c|c|c|c|c|}
\hline $\begin{array}{l}\text { Spot } \\
\text { ID }\end{array}$ & UniProt ID ${ }^{a}$ & Protein name & $\begin{array}{l}\text { Mass (Da) } \\
\quad(\mathrm{T} / \mathrm{C})\end{array}$ & $\begin{array}{c}\text { pI } \\
(\mathrm{T} / \mathrm{C})\end{array}$ & Score & $\begin{array}{l}\text { Peptide } \\
\text { matching }\end{array}$ & $\begin{array}{l}\text { Coverage } \\
(\%)\end{array}$ & Source \\
\hline 1 & Q4EJN0_LISMO & Translation elongation factor $\mathrm{G}$ & $76973 / 81510$ & $4.85 / 5.10$ & 2193 & $27 / 36$ & 53 & $\begin{array}{l}\text { L. monocytogenes } \\
\text { str. } 4 \mathrm{~b} \mathrm{H} 7858\end{array}$ \\
\hline 2 & Q4EPL3_LISMO & Transketolase & $71831 / 78240$ & $5.11 / 5.37$ & 1789 & $19 / 26$ & 50 & $\begin{array}{l}\text { L.monocytogenes } \\
\text { str. } 1 / 2 \text { a F6854 }\end{array}$ \\
\hline 3 & Q8Y6W1_LISMO & Pyruvate kinase & $62673 / 75770$ & $5.39 / 5.15$ & 810 & $22 / 25$ & 52 & $\begin{array}{l}\text { L. monocytogenes } \\
\text { EGD }\end{array}$ \\
\hline 4 & Q4EGL2_LISMO & Chaperone protein DnaK & $66118 / 72340$ & $4.57 / 4.57$ & 1730 & $23 / 39$ & 50 & $\begin{array}{l}\text { L. monocytogenes } \\
\text { str. } 4 \mathrm{~b} \mathrm{H} 7858\end{array}$ \\
\hline 5 & Q4EEZ8_LISMO & $60 \mathrm{kDa}$ chaperonin, GroEL & $57332 / 67860$ & $4.72 / 4.80$ & 2439 & $28 / 42$ & 66 & $\begin{array}{l}\text { L. monocytogenes } \\
\text { str. } 4 \mathrm{~b} \text { H7858 }\end{array}$ \\
\hline 7 & Q4EKN1_LISMO & GMP synthase & $57799 / 70490$ & $4.95 / 5.19$ & 1431 & $26 / 33$ & 57 & $\begin{array}{l}\text { L. monocytogenes } \\
\text { str. } 4 \mathrm{~b} \mathrm{H} 7858\end{array}$ \\
\hline 9 & Q4ET64_LISMO & $\begin{array}{c}\text { Phosphoribosylaminoimidazolecar- } \\
\text { boxamide formyltransferase/IMP } \\
\text { cyclohydrolase }\end{array}$ & $55022 / 75560$ & $5.27 / 5.61$ & 1530 & $20 / 27$ & 53 & $\begin{array}{l}\text { L.monocytogenes } \\
\text { str. 1/2a F6854 }\end{array}$ \\
\hline 11 & Q4EH88_LISMO & Formate-tetrahydrofolate ligase & $60390 / 67750$ & $5.45 / 5.55$ & 1041 & $19 / 25$ & 40 & $\begin{array}{l}\text { L. monocytogenes } \\
\text { str. } 4 \mathrm{~b} \mathrm{H} 7858\end{array}$ \\
\hline 13 & Q4EPH5_LISMO & Homoserine dehydrogenase & $46430 / 59120$ & $5.13 / 5.25$ & 548 & $7 / 14$ & 24 & $\begin{array}{l}\text { L.monocytogenes } \\
\text { str. 1/2a F6854 }\end{array}$ \\
\hline 15 & Q8Y5W7_LISMO & Lmo1938 protein & $41406 / 57360$ & $4.47 / 4.43$ & 1092 & $19 / 30$ & 55 & $\begin{array}{l}\text { L. monocytogenes } \\
\text { EGD }\end{array}$ \\
\hline 16 & Q4EEP6_LISMO & Enolase & $46458 / 68940$ & $4.70 / 4.82$ & 2400 & $23 / 26$ & 79 & $\begin{array}{l}\text { L. monocytogenes } \\
\text { str. } 4 \mathrm{~b} \mathrm{H} 7858\end{array}$ \\
\hline 17 & Q4EJM9_LISMO & Elongation factor $\mathrm{Tu}$ & $43429 / 51410$ & $4.81 / 4.90$ & 1873 & $29 / 36$ & 82 & $\begin{array}{l}\text { L. monocytogenes } \\
\text { str. } 4 \mathrm{~b} \mathrm{H} 7858\end{array}$ \\
\hline 19 & Q4EST8_LISMO & $\begin{array}{c}\text { Beta-ketoacyl-acyl carrier protein } \\
\text { synthase II }\end{array}$ & $44423 / 63600$ & $5.26 / 5.58$ & 567 & $11 / 30$ & 45 & $\begin{array}{l}\text { L.monocytogenes } \\
\text { str. 1/2a F6854 }\end{array}$ \\
\hline 20 & Q4EED3_LISMO & Serine hydroxymethyltransferase & $45178 / 58240$ & $5.53 / 5.88$ & 702 & $11 / 13$ & 36 & $\begin{array}{l}\text { L. monocytogenes } \\
\text { str. } 4 \mathrm{~b} \mathrm{H} 7858\end{array}$ \\
\hline 21 & Q4EID3_LISMO & $\begin{array}{l}\text { Glutamate dehydrogenase, } \\
\text { NADP-specific }\end{array}$ & $49449 / 58800$ & $5.54 / 6.00$ & 1368 & $19 / 22$ & 62 & $\begin{array}{l}\text { L. monocytogenes } \\
\text { str. } 4 \mathrm{~b} \mathrm{H} 7858\end{array}$ \\
\hline 22 & Q4EHL3_LISMO & Isocitrate dehydrogenase [NADP] & $46289 / 54480$ & $5.24 / 5.47$ & 610 & $12 / 15$ & 31 & $\begin{array}{l}\text { L.monocytogenes } \\
\text { str. 1/2a F6854 }\end{array}$ \\
\hline 23 & ACKA2_LISMF & Acetate kinase 2 & $43860 / 50290$ & $5.31 / 5.65$ & 97 & $10 / 31$ & 25 & $\begin{array}{l}\text { L.monocytogenes } \\
\text { str. } 4 \mathrm{~b} \quad \text { F2365 }\end{array}$ \\
\hline 25 & Q4EEZ6_LISMO & $\begin{array}{c}\text { Chorismate } \\
\text { mutase/phospho-2-dehydro-3-deoxyhep } \\
\text { tonate aldolase }\end{array}$ & $35826 / 52050$ & $5.79 / 5.60$ & 662 & $11 / 25$ & 39 & $\begin{array}{l}\text { L. monocytogenes } \\
\text { str. } 4 \mathrm{~b} \mathrm{H} 7858\end{array}$ \\
\hline 26 & Q4EN62_LISMO & Tryptophan synthase, beta subunit & $43921 / 49070$ & $5.50 / 5.98$ & 680 & $11 / 12$ & 38 & $\begin{array}{l}\text { L.monocytogenes } \\
\text { str. 1/2a F6854 }\end{array}$ \\
\hline 31 & Q4EP90_LISMO & Catabolite control protein A (Fragment) & $31566 / 43010$ & $5.05 / 5.05$ & 564 & $8 / 11$ & 34 & $\begin{array}{l}\text { L.monocytogenes } \\
\text { str. 1/2a F6854 }\end{array}$ \\
\hline 32 & Q8Y4I1_LISMO & $\begin{array}{l}\text { Glyceraldehyde 3-phosphate } \\
\text { dehydrogenase (Gap protein) }\end{array}$ & $36435 / 45060$ & $5.20 / 5.20$ & 2353 & $14 / 20$ & 71 & $\begin{array}{l}\text { L. monocytogenes } \\
\text { EGD }\end{array}$ \\
\hline 33 & LDH1_LISMF & L-lactate dehydrogenase 1 & $34284 / 42290$ & $5.20 / 5.20$ & 106 & $12 / 41$ & 34 & $\begin{array}{l}\text { L.monocytogenes } \\
\text { str. 4b } \quad \text { F2365 }\end{array}$ \\
\hline 37 & Q4EUJ0_LISMO & $\begin{array}{l}\text { PTS system, mannose-specific, IIAB } \\
\text { component }\end{array}$ & $34972 / 40190$ & $5.33 / 5.33$ & 767 & $13 / 23$ & 60 & $\begin{array}{l}\text { L.monocytogenes } \\
\text { str. 1/2a F6854 }\end{array}$ \\
\hline 38 & K6PF_LISMF & 6-phosphofructokinase & $34399 / 40280$ & $5.46 / 5.46$ & 203 & $17 / 30$ & 52 & $\begin{array}{l}\text { L.monocytogenes } \\
\text { str. } 4 \mathrm{~b} \quad \text { F2365 }\end{array}$ \\
\hline 40 & Q8YAC3_LISMO & Cysteine synthase & $32198 / 34880$ & $5.32 / 5.32$ & 1257 & $12 / 18$ & 66 & $\begin{array}{l}\text { L. monocytogenes } \\
\text { EGD }\end{array}$ \\
\hline 41 & DAAA_LISMO & D-alanine aminotransferase & $32554 / 33400$ & $5.12 / 5.12$ & 153 & $11 / 22$ & 50 & $\begin{array}{l}\text { L. monocytogenes } \\
\text { EGD }\end{array}$ \\
\hline
\end{tabular}




\section{Continued}

\begin{tabular}{|c|c|c|c|c|c|c|c|c|}
\hline 42 & PANB_LISMO & $\begin{array}{l}\text { 3-methyl-2-oxobutanoate } \\
\text { hydroxymethyltransferase }\end{array}$ & $29836 / 31330$ & $5.27 / 5.27$ & 54 & $7 / 39$ & 32 & $\begin{array}{l}\text { L. monocytogenes } \\
\text { EGD }\end{array}$ \\
\hline 47 & A1E155_LISMO & General stress protein $\mathrm{Ctc}$ & $22641 / 27850$ & $4.44 / 4.44$ & 1287 & $11 / 15$ & 61 & $\begin{array}{l}\text { L. monocytogenes } \\
\text { EGD }\end{array}$ \\
\hline 54 & Q4EEP4_LISMO & Triosephosphate isomerase & $27073 / 25310$ & $4.78 / 4.76$ & 1287 & $8 / 11$ & 33 & $\begin{array}{l}\text { L. monocytogenes } \\
\text { str. } 4 \mathrm{~b} \mathrm{H} 7858\end{array}$ \\
\hline 56 & Q8Y6H5 & Methionine aminopeptidase & $27999 / 30960$ & $5.32 / 5.32$ & 69 & $5 / 13$ & 32 & $\begin{array}{l}\text { L. monocytogenes } \\
\text { EGD }\end{array}$ \\
\hline 57 & Q8Y971 & $\begin{array}{l}\text { Hypothetical protein lmo } 0662 \text {; } \\
\text { thiamin biosynthetic process }\end{array}$ & $28915 / 28360$ & $5.25 / 5.25$ & 127 & $9 / 10$ & 45 & $\begin{array}{l}\text { L. monocytogenes } \\
\text { EGD }\end{array}$ \\
\hline 59 & Q4EJS8_LISMO & Oxidoreductase & $32593 / 33540$ & $5.87 / 5.87$ & 1091 & $16 / 23$ & 61 & $\begin{array}{l}\text { L. monocytogenes } \\
\text { str. } 4 \mathrm{~b} \mathrm{H} 7858\end{array}$ \\
\hline 60 & Q4EST3_LISMO & $\begin{array}{l}\text { Redox-sensing transcriptional } \\
\text { repressor rex }\end{array}$ & $24185 / 28590$ & $5.78 / 5.78$ & 427 & $9 / 19$ & 56 & $\begin{array}{l}\text { L.monocytogenes } \\
\text { str. 1/2a F6854 }\end{array}$ \\
\hline 61 & Q4EUU3_LISMO & $\begin{array}{l}\text { 2-C-methyl-D-erythritol 4-phosphate } \\
\text { cytidylyltransferase }\end{array}$ & $26809 / 27670$ & $5.71 / 5.71$ & 719 & $14 / 19$ & 57 & $\begin{array}{l}\text { L.monocytogenes } \\
\text { str. 1/2a F6854 }\end{array}$ \\
\hline 63 & PYRE_LISMF & Orotate phosphoribosyltransferase & $22849 / 22630$ & $5,27 / 5,27$ & 68 & $5 / 14$ & 29 & $\begin{array}{l}\text { L.monocytogenes } \\
\text { str. } 4 \mathrm{~b} \quad \text { F2365 }\end{array}$ \\
\hline 64 & Q4EUT9_LISMO & $\begin{array}{l}\text { DTDP-4-dehydrorhamnose } \\
\text { 3,5-epimerase }\end{array}$ & $21149 / 21490$ & $5.63 / 6.10$ & 582 & $4 / 10$ & 22 & $\begin{array}{l}\text { L.monocytogenes } \\
\text { str. 1/2a F6854 }\end{array}$ \\
\hline 69 & Q4ETU5_LISMO & Superoxide dismutase & $22617 / 19540$ & $5.23 / 5.47$ & 3310 & $10 / 12$ & 60 & $\begin{array}{l}\text { L.monocytogenes } \\
\text { str. 1/2a F6854 }\end{array}$ \\
\hline 72 & Q4EDN9_LISMO & $\begin{array}{l}\text { Transcription antitermination protein } \\
\text { nusG }\end{array}$ & $19928 / 17160$ & $5.16 / 5.51$ & 487 & $6 / 15$ & 44 & $\begin{array}{l}\text { L. monocytogenes } \\
\text { str. } 4 \mathrm{~b} \mathrm{H} 7858\end{array}$ \\
\hline 73 & Q4EPZ2_LISMO & Thiol peroxidase & $18208 / 15820$ & $5.21 / 5.50$ & 2484 & $6 / 10$ & 52 & $\begin{array}{l}\text { L.monocytogenes } \\
\text { str. 1/2a F6854 }\end{array}$ \\
\hline 75 & Q8Y4I1_LISMO & $\begin{array}{l}\text { Glyceraldehyde 3-phosphate } \\
\text { dehydrogenase (Gap protein) }\end{array}$ & $36435 / 15810$ & $5.20 / 5.08$ & 583 & $7 / 11$ & 25 & $\begin{array}{l}\text { L. monocytogenes } \\
\text { EGD }\end{array}$ \\
\hline 77 & Q4ERJ3_LISMO & Peroxide resistance protein Dpr & $18036 / 13820$ & $4.86 / 5.15$ & 1492 & $11 / 13$ & 93 & $\begin{array}{l}\text { L.monocytogenes } \\
\text { str. 1/2a F6854 }\end{array}$ \\
\hline 84 & Q4ESL7_LISMO & S1 RNA binding domain protein & $13011 / 7260$ & $5.39 / 5.73$ & 584 & $5 / 8$ & 47 & $\begin{array}{l}\text { L.monocytogenes } \\
\text { str. 1/2a F6854 }\end{array}$ \\
\hline 88 & Q4ER91_LISMO & Phosphocarrier protein $\mathrm{HPr}$ & $9398 / 7740$ & $4.81 / 4.96$ & 736 & $7 / 13$ & 56 & $\begin{array}{l}\text { L.monocytogenes } \\
\text { str. 1/2a F6854 }\end{array}$ \\
\hline 87 & Q4EUP5_LISMO & Ribosomal protein S6 & $11500 / 6110$ & $5.08 / 5.36$ & 1740 & $7 / 19$ & 74 & $\begin{array}{l}\text { L.monocytogenes } \\
\text { str. 1/2a F6854 }\end{array}$ \\
\hline 91 & Q8Y6Q0_LISMO & $\begin{array}{l}\text { Lmo1634 protein (similar to alcohol } \\
\text { dehydrogenase) }\end{array}$ & $95135 / 83280$ & $6.48 / 6.90$ & 2120 & $30 / 36$ & 57 & $\begin{array}{l}\text { L. monocytogenes } \\
\text { EGD }\end{array}$ \\
\hline 92 & Q4EU28_LISMO & Phosphomethylpyrimidine kinase & $28915 / 28250$ & $5.25 / 5.55$ & 879 & $12 / 13$ & 57 & $\begin{array}{l}\text { L.monocytogenes } \\
\text { str. 1/2a F6854 }\end{array}$ \\
\hline 99 & Q4EMI9_LISMO & 50 S ribosomal protein $\mathrm{L} 21$ & $11022 / 7390$ & $9.64 / 4.21$ & 989 & $5 / 15$ & 58 & $\begin{array}{l}\text { L.monocytogenes } \\
\text { str. 1/2a F6854 }\end{array}$ \\
\hline 100 & Q4EVM9_LISMO & Heme-degrading monooxygenase isdG & $13777 / 10007$ & $5.96 / 6.65$ & 1313 & $4 / 12$ & 34 & $\begin{array}{l}\text { L.monocytogenes } \\
\text { str. 1/2a F6854 }\end{array}$ \\
\hline 101 & Q4ENX9_LISMO & 50 S ribosomal protein $\mathrm{L} 17$ & $15205 / 10970$ & $10.27 / 6.92$ & 1824 & $6 / 20$ & 45 & $\begin{array}{l}\text { L.monocytogenes } \\
\text { str. 1/2a F6854 }\end{array}$ \\
\hline 102 & Q4ENW9_LISMO & Ribosomal protein S5 & $17445 / 13140$ & $9.43 / 6.92$ & 1529 & $9 / 16$ & 68 & $\begin{array}{l}\text { L.monocytogenes } \\
\text { str. 1/2a F6854 }\end{array}$ \\
\hline 104 & Q9RQJ0_LISMO & $\begin{array}{l}\text { Lmo1601 protein (Stress protein-like } \\
\text { protein) }\end{array}$ & $18435 / 17480$ & $7.71 / 6.90$ & 464 & $7 / 16$ & 28 & $\begin{array}{l}\text { L. monocytogenes } \\
\text { EGD }\end{array}$ \\
\hline 105 & Q4ENW4_LISMO & 50S ribosomal protein L5 & $19983 / 19540$ & $9.02 / 6.93$ & 661 & $9 / 13$ & 65 & $\begin{array}{l}\text { L.monocytogenes } \\
\text { str. 1/2a F6854 }\end{array}$ \\
\hline 106 & Q4EDU9_LISMO & Ribosomal protein L1 & $24531 / 26340$ & $9.32 / 6.94$ & 3412 & $13 / 22$ & 54 & $\begin{array}{l}\text { L. monocytogenes } \\
\text { str. } 4 \mathrm{~b} \mathrm{H} 7858\end{array}$ \\
\hline 108 & Q4ERT5_LISMO & $\begin{array}{l}\text { Pyruvate dehydrogenase complex, E1 } \\
\text { component }\end{array}$ & $41241 / 51450$ & $6.05 / 6.72$ & 1498 & $18 / 22$ & 51 & $\begin{array}{l}\text { L.monocytogenes } \\
\text { str. 1/2a F6854 }\end{array}$ \\
\hline
\end{tabular}




\section{Continued}

\begin{tabular}{|c|c|c|c|c|c|c|c|c|}
\hline 128 & Q4EN63_LISMO & Tryptophan synthase alpha chain & $27930 / 24730$ & $5,51 / 5,65$ & 298 & $6 / 10$ & 32 & $\begin{array}{l}\text { L.monocytogenes } \\
\text { str. } 1 / 2 \text { a F6854 }\end{array}$ \\
\hline 132 & Q4ERM9_LISMO & Ribose-phosphate pyrophosphokinase & $35275 / 36490$ & $5.83 / 6.45$ & 1858 & $11 / 13$ & 41 & $\begin{array}{l}\text { L.monocytogenes } \\
\text { str. 1/2a F6854 }\end{array}$ \\
\hline 139 & Q4EHC3_LISMO & $\begin{array}{l}\text { Quinolinate synthetase complex, } \\
\text { subunit A }\end{array}$ & $41591 / 49610$ & $5.87 / 5.90$ & 390 & $12 / 15$ & 53 & $\begin{array}{l}\text { L. monocytogenes } \\
\text { str. } 4 \mathrm{~b} \mathrm{H} 7858\end{array}$ \\
\hline 141 & Q84DR8_LISMO & Invasion associated protein $\mathrm{p} 60$ & $48162 / 64290$ & $9.02 / 6.94$ & 637 & $11 / 16$ & 30 & $\begin{array}{l}\text { L. monocytogenes } \\
\text { EGD }\end{array}$ \\
\hline 144 & Q4EN85_LISMO & Chorismate synthase & $42260 / 56430$ & $6.59 / 6.35$ & 899 & $13 / 19$ & 49 & $\begin{array}{l}\text { L.monocytogenes } \\
\text { str. 1/2a F6854 }\end{array}$ \\
\hline 148 & Q4ETZ9_LISMO & GTPase, putative & $40616 / 50470$ & $6.13 / 6.86$ & 417 & $11 / 23$ & 46 & $\begin{array}{l}\text { L.monocytogenes } \\
\text { str. 1/2a F6854 }\end{array}$ \\
\hline 149 & Q4EK69_LISMO & Adenylosuccinate synthetase & $47818 / 65310$ & $5.57 / 6.06$ & 2570 & $13 / 17$ & 32 & $\begin{array}{l}\text { L. monocytogenes } \\
\text { str. } 4 \mathrm{~b} \text { H7858 }\end{array}$ \\
\hline 160 & Q4ET66_LISMO & $\begin{array}{l}\text { Phosphoribosylformylglycinamidine } \\
\text { cyclo-ligase }\end{array}$ & $37490 / 44020$ & $4.61 / 4.74$ & 1295 & $13 / 24$ & 70 & $\begin{array}{l}\text { L.monocytogenes } \\
\text { str. 1/2a F6854 }\end{array}$ \\
\hline 167 & Q8Y6L1_LISMO & Naphthoate synthase & $30176 / 29300$ & $5.15 / 5.28$ & 3614 & $13 / 15$ & 49 & $\begin{array}{l}\text { L. monocytogenes } \\
\text { EGD }\end{array}$ \\
\hline 168 & Q4EQ78_LISMO & Septum site-determining protein MinD & $29219 / 30590$ & $5.03 / 5.29$ & 1412 & $7 / 9$ & 35 & $\begin{array}{l}\text { L.monocytogenes } \\
\text { str. 1/2a F6854 }\end{array}$ \\
\hline 176 & Q4EDU9_LISMO & Ribosomal protein L1 & $24531 / 30330$ & $9.32 / 4.72$ & 2969 & $10 / 20$ & 42 & $\begin{array}{l}\text { L. monocytogenes } \\
\text { str. } 4 \mathrm{~b} \mathrm{H7858}\end{array}$ \\
\hline 179 & Q4ET69_LISMO & $\begin{array}{l}\text { Phosphoribosylformylglycinamidine } \\
\text { synthase I }\end{array}$ & $25170 / 24450$ & $4.71 / 4.74$ & 2491 & $8 / 18$ & 35 & $\begin{array}{l}\text { L.monocytogenes } \\
\text { str. } 1 / 2 \text { a F6854 }\end{array}$ \\
\hline 189 & Q8Y4C5_LISMO & Mbl protein & $35785 / 45850$ & $5.45 / 5.86$ & 745 & $12 / 21$ & 51 & $\begin{array}{l}\text { L. monocytogenes } \\
\text { EGD }\end{array}$ \\
\hline 195 & Q8Y689_LISMO & $\begin{array}{l}\text { FabD protein (Malonyl CoA-acyl } \\
\text { carrier protein transacylase) }\end{array}$ & $32970 / 38250$ & $4.79 / 4.91$ & 915 & $12 / 18$ & 60 & $\begin{array}{l}\text { L. monocytogenes } \\
\text { EGD }\end{array}$ \\
\hline 202 & RECA_LISMO & Protein RecA & $37971 / 49520$ & $5.09 / 5.47$ & 114 & $12 / 19$ & 30 & $\begin{array}{l}\text { L. monocytogenes } \\
\text { EGD }\end{array}$ \\
\hline 203 & Q8Y4I1_LISMO & $\begin{array}{l}\text { Glyceraldehyde } 3 \text {-phosphate } \\
\text { dehydrogenase (Gap protein) }\end{array}$ & $36435 / 45060$ & $5.20 / 5.42$ & 1491 & $18 / 22$ & 51 & $\begin{array}{l}\text { L. monocytogenes } \\
\text { EGD }\end{array}$ \\
\hline 205 & Q4ERT8_LISMO & Dihydrolipoyl dehydrogenase & $49571 / 69160$ & $5.24 / 5.62$ & 4837 & $17 / 21$ & 46 & $\begin{array}{l}\text { L.monocytogenes } \\
\text { str. 1/2a F6854 }\end{array}$ \\
\hline 229 & Q4ERT8_LISMO & $\begin{array}{l}\text { Dihydrolipoyl dehydrogenase, Pyruvate } \\
\text { dehydrogenase complex, E3 component }\end{array}$ & $49571 / 69160$ & $5.24 / 6.63$ & 1084 & $10 / 28$ & 29 & $\begin{array}{l}\text { L.monocytogenes } \\
\text { str. 1/2a F6854 }\end{array}$ \\
\hline 233 & Q8Y4M3_LISMO & Lmo2414 (iron-sulfur cluster assembly) & $48072 / 55130$ & $5.61 / 5.75$ & 811 & $10 / 10$ & 23 & $\begin{array}{l}\text { L. monocytogenes } \\
\text { EGD }\end{array}$ \\
\hline 251 & Q4EP84_LISMO & $\begin{array}{c}\text { UDP-N-acetylmuramate-alanine } \\
\text { ligase }\end{array}$ & $50223 / 26650$ & $5.47 / 4.92$ & 1849 & $14 / 15$ & 37 & $\begin{array}{l}\text { L.monocytogenes } \\
\text { str. 1/2a F6854 }\end{array}$ \\
\hline 267 & Q8Y6W1_LISMO & Pyruvate kinase & $62673 / 85320$ & $5.39 / 5.76$ & 3661 & $18 / 20$ & 48 & $\begin{array}{l}\text { L. monocytogenes } \\
\text { EGD }\end{array}$ \\
\hline 268 & Q4ESF0_LISMO & $\begin{array}{l}\text { Polyribonucleotide } \\
\text { nucleotidyltransferase }\end{array}$ & $79720 / 104810$ & $5.23 / 5.62$ & 2042 & $11 / 11$ & 19 & $\begin{array}{l}\text { L.monocytogenes } \\
\text { str. 1/2a F6854 }\end{array}$ \\
\hline 271 & Q4EQU8_LISMO & Aspartate aminotransferase, putative & $43388 / 48820$ & $5.50 / 5.55$ & 1155 & $15 / 21$ & 50 & $\begin{array}{l}\text { L.monocytogenes } \\
\text { str. } 1 / 2 \text { a F6854 }\end{array}$ \\
\hline 275 & Q4EMT5_LISMO & Methionine aminopeptidase & $27979 / 29560$ & $5.39 / 4.95$ & 360 & $7 / 10$ & 48 & $\begin{array}{l}\text { L.monocytogenes } \\
\text { str. } 1 / 2 \text { a F6854 }\end{array}$ \\
\hline 277 & Q8Y6S6_LISMO & PheT protein & $22581 / 22780$ & $4.82 / 4.85$ & 666 & $10 / 15$ & 53 & $\begin{array}{l}\text { L. monocytogenes } \\
\text { EGD }\end{array}$ \\
\hline 280 & Q4ENQ7_LISMO & Autoinducer-2 production protein LuxS & $17528 / 14210$ & $5.32 / 5.45$ & 219 & $3 / 11$ & 20 & $\begin{array}{l}\text { L.monocytogenes } \\
\text { str. } 1 / 2 \text { a F6854 }\end{array}$ \\
\hline
\end{tabular}




\begin{tabular}{|c|c|c|c|c|c|c|c|c|}
\hline & & Extracellular proteins & & & & & & \\
\hline 12 & Q8Y9G8 & $\begin{array}{l}\text { Lmo0560 protein, similar to } \\
\text { NADP-specific glutamate } \\
\text { dehydrogenase }\end{array}$ & $49464 / 51880$ & $5.54 / 5.40$ & 1224 & $32 / 33$ & 64 & $\begin{array}{l}\text { L. monocytogenes } \\
\text { EGD }\end{array}$ \\
\hline \multirow[t]{2}{*}{28} & P64075 & Hypothetical protein lin2549 (enolase) & $46444 / 49940$ & $4.70 / 4.65$ & 2010 & $50 / 52$ & 76 & $\begin{array}{c}\text { L. innocua str. Clip } \\
11262\end{array}$ \\
\hline & $\begin{array}{c}\text { Q8YAW1_LISM } \\
\text { O }\end{array}$ & DNA polimerase III subunit beta & 42403 & 4.70 & 482 & $15 / 16$ & 35 & $\begin{array}{l}\text { L. monocytogenes } \\
\text { EGD }\end{array}$ \\
\hline $29^{*}$ & Q8Y4I2 & Phosphoglycerate kinase & $42135 / 46850$ & $4.97 / 4.85$ & 1418 & $42 / 44$ & 71 & $\begin{array}{l}\text { L. monocytogenes } \\
\text { EGD }\end{array}$ \\
\hline $33^{*}$ & Q9RE04 & Peptidoglycan lytic protein P45 & $42743 / 44570$ & $8.56 / 6.20$ & 1223 & $32 / 34$ & 45 & $\begin{array}{l}\text { L. monocytogenes } \\
\text { EGD }\end{array}$ \\
\hline $34^{*}$ & Q9RE04 & Peptidoglycan lytic protein P45 & $42743 / 44570$ & $8.56 / 6.6$ & 1349 & $35 / 38$ & 48 & $\begin{array}{l}\text { L. monocytogenes } \\
\text { EGD }\end{array}$ \\
\hline 39 & Q8Y4I1 & $\begin{array}{l}\text { Glyceraldehyde-3-phosphate } \\
\text { dehydrogenase }\end{array}$ & $36435 / 43750$ & $5.20 / 5.10$ & 1350 & $43 / 48$ & 71 & $\begin{array}{l}\text { L. monocytogenes } \\
\text { EGD }\end{array}$ \\
\hline 46 & Q8Y6Y3 & MreB protein & $35595 / 39800$ & $5.16 / 5.20$ & 743 & $14 / 15$ & 42 & $\begin{array}{l}\text { L. monocytogenes } \\
\text { EGD }\end{array}$ \\
\hline 55 & Q8YAM2 & EIIMant PTS permease IIAB subunit & $34972 / 36200$ & $5.33 / 5.30$ & 781 & $23 / 28$ & 76 & $\begin{array}{l}\text { L. monocytogenes } \\
\text { EGD }\end{array}$ \\
\hline $63^{*}$ & Q71X80 & Amino acid $\mathrm{ABC}$ transporter & $29614 / 24780$ & $6.64 / 5.45$ & 1028 & $33 / 39$ & 61 & $\begin{array}{l}\text { L. monocytogenes } \\
\text { str. } 4 \mathrm{~b} \text { F2365 }\end{array}$ \\
\hline $69^{*}$ & Q722W8 & Invasion associated protein $\mathrm{P} 60$ & $48162 / 59780$ & $9.23 / 9.50$ & 1461 & $52 / 63$ & 62 & $\begin{array}{l}\text { L. monocytogenes } \\
\text { EGD }\end{array}$ \\
\hline $74^{*}$ & Q8Y7E9 & $\begin{array}{l}\text { Lmo1333, similar to B. subtilis YqzC } \\
\text { protein }\end{array}$ & $17884 / 11030$ & $9.11 / 7.80$ & 176 & $9 / 9$ & 23 & $\begin{array}{l}\text { L. monocytogenes } \\
\text { EGD }\end{array}$ \\
\hline $108^{*}$ & Q8Y665 & $\begin{array}{c}\text { Carbamoyl-phosphate synthase large } \\
\text { chain }\end{array}$ & $118272 / 96280$ & $4.79 / 4.75$ & 1709 & $38 / 40$ & 38 & $\begin{array}{l}\text { L. monocytogenes } \\
\text { EGD }\end{array}$ \\
\hline 109 & Q8Y7F1 & $\begin{array}{l}\text { Polyribonucleotide } \\
\text { nucleotidyltransferase }\end{array}$ & $79780 / 82620$ & $5.23 / 5.25$ & 1771 & $42 / 48$ & 55 & $\begin{array}{l}\text { L. monocytogenes } \\
\text { EGD }\end{array}$ \\
\hline $110^{*}$ & Q8Y6W1 & Pyruvate kinase & $62673 / 73100$ & $5.39 / 5.37$ & 1552 & $41 / 45$ & 65 & $\begin{array}{l}\text { L. monocytogenes } \\
\text { EGD }\end{array}$ \\
\hline $111^{*}$ & Q9KGV9 & $\begin{array}{l}\text { Lmo2185 protein (SvpA, } \\
\text { P64 protein ) }\end{array}$ & $63341 / 71620$ & $6.44 / 5.30$ & 644 & $16 / 17$ & 42 & $\begin{array}{l}\text { L. monocytogenes } \\
\text { EGD }\end{array}$ \\
\hline $115^{*}$ & P66700 & $\begin{array}{l}\text { DNA-directed RNA polymerase } \\
\text { subunit alpha }\end{array}$ & $34941 / 46190$ & $4.80 / 4.75$ & 807 & $23 / 26$ & 50 & $\begin{array}{l}\text { L. innocua str. Clip } \\
\quad 11262\end{array}$ \\
\hline \multirow[t]{2}{*}{$116^{*}$} & A0AJ50 & $\begin{array}{c}\text { Bifunctional } \\
\text { 3-deoxy-7-phosphoheptulonate } \\
\text { synthase/Chorismate mutase }\end{array}$ & $39832 / 49110$ & $5.25 / 5.60$ & 1125 & $27 / 31$ & 47 & $\begin{array}{l}\text { L. welshimeri } \\
\text { serovar } 6 \mathrm{~b} \text { str. } \\
\text { SLCC5334 }\end{array}$ \\
\hline & & $\begin{array}{c}\text { Bifunctional } \\
\text { 3-deoxy-7-phosphoheptulonate } \\
\text { synthase/Chorismate mutase }\end{array}$ & 39831 & 5.41 & 1100 & $27 / 30$ & 47 & $\begin{array}{l}\text { L. monocytogenes } \\
\text { EGD }\end{array}$ \\
\hline $117^{*}$ & Q8Y444 & 50S ribosomal protein L6 & $19388 / 19210$ & $9.75 / 5.50$ & 516 & $13 / 15$ & 57 & $\begin{array}{l}\text { L. monocytogenes } \\
\text { EGD }\end{array}$ \\
\hline $121^{*}$ & Q7ANT6 & $\begin{array}{l}\text { Similar to inosine-monophosphate } \\
\text { dehydrogenase }\end{array}$ & $52637 / 58580$ & $6.06 / 5.50$ & 550 & $13 / 13$ & 27 & $\begin{array}{l}\text { L. innocua str. Clip } \\
\quad 11262\end{array}$ \\
\hline $128^{*}$ & Q8Y4I4 & Phosphoglyceratemutase & $56104 / 65100$ & $4.73 / 5.45$ & 1250 & $29 / 33$ & 48 & $\begin{array}{l}\text { L. monocytogenes } \\
\text { EGD }\end{array}$ \\
\hline $202^{*}$ & Q8Y581 & $\begin{array}{l}\text { Lmo2192 protein, similar to } \\
\text { oligopeptide ABC transporter }\end{array}$ & $36712 / 37240$ & $6.85 / 6.25$ & 874 & $19 / 22$ & 47 & $\begin{array}{l}\text { L. monocytogenes } \\
\text { EGD }\end{array}$ \\
\hline $214^{*}$ & Q8Y5N3 & $\begin{array}{l}\text { NadC protein, similar to } \\
\text { nicotinate-nucleotide } \\
\text { pyrophosphorylase }\end{array}$ & $30585 / 25990$ & $7.02 / 6.40$ & 608 & $17 / 17$ & 54 & $\begin{array}{l}\text { L. monocytogenes } \\
\text { EGD }\end{array}$ \\
\hline
\end{tabular}

${ }^{\mathrm{a}}$ For each spot identification the hit with the top score is indicated and where applicable the hit for L. monocytogenes EGD is shown; ${ }^{*}$ protein spots identified by LC/MS-MS, the remaining were identified by MALDI-TOF. 